\title{
Geophysical Investigations in the Colorado Delta Region ${ }^{1}$
}

\author{
Robert L. Kovach, ${ }^{2}$ Clakence R. Allen, and Frank Press \\ Seismological Laboratory and Division of the Geological Sciences \\ California Institute of Technology, Pasadena
}

\begin{abstract}
The combined approach of gravity and seismic refraction techniques was used to determine depths of the Cenozoic section and fault patterns of the Colorado delta region. Bouguer gravity anomalies range from -10 to $-88 \mathrm{mgal}$ with respect to the International Ellipsoid, and the trend of isogal contours is northwesterly. In the center of the basin, depths to basement estimated from gravity data are less than known minimum depths determined from seismic refraction profiles. This discrepancy suggests density complexities within the deeper parts of the stratigraphic section, an interpretation that is supported by sparse measurements from well samples; local isostatic compensation may also contribute to the discrepancy but is not thought to be the major cause. Measured seismic velocities ranged from 5650 to $20,000 \mathrm{ft} / \mathrm{sec}$, and several consistent velocity zones were widespread above the pre-Tertiary basement; indicated depths to basement varied from 2200 feet to at least 15,400 feet, the greatest depth being near the international border. Many members of the San Andreas fault system are well delineated by gravity and seismic data, including the Eleinore and San Jacinto faults and a fault beneath the Sand Hills. Of these, the San Jacinto fault appears to be the most continuous through the delta region, but all appear to be en echelon to the trend of the San Andreas fault system as a whole.
\end{abstract}

\section{INTRODUCTION}

The Colorado delta region is part of the complex structural trough that continues northwesterly from the Gulf of California. Sedimentation has occurred in this part of the trough intermittently since Miocene time, yet little is known of either the thickness and nature of the Cenozoic sediments or of the configuration of the underlying crystalline rocks. This lack of knowledge is due primarily to the fact that Quaternary alluvium covers most of the region, and thus geophysical techniques have been used in this study as the principal means of investigation. Inasmuch as the tectonic framework of the delta region, as well as that of the Gulf of California, is controlled in a gross way by the San Andreas fault zone, it was hoped that a geophysical study might help to decipher the stratigraphic and structural history of the region and might also contribute to the understanding of the fault zone itself.

A combined approach of gravity and seismic exploration was used in the field; about 1250

\footnotetext{
1 Contribution 1069, Division of Geological Sciences, California Institute of Technology.

${ }^{2}$ Now at the Jet Propulsion Laboratory, Pasadena, California.
}

gravity observations were obtained, and 8 seismic refraction profiles were shot. In addition, limited geological reconnaissance was carried out in little-known regions south of the international border.

\section{Gentral Geologic Setting}

We refer to the area of this study as the Colorado delta region because the structural trough of the Gulf of California is here filled by the combined fan and delta of the Colorado River (Fig. 1). The apex of this great deltaic cone is at the eastern edge of the trough near Yuma, Arizona, and the delta forms a natural dam that prevents marine waters of the Gulf of California from flooding the depressed Salton Sea area north of the delta. Within recent history, the Colorado River has taken various paths across its deltaic cone, at times emptying into the Gulf of California and at times emptying into the land-locked Salton Sea. The latest marine incursion into the Salton Sea area was in middle Pleistocene time [Downs and Woodard, 1961], and marine sediments within the region indicate that earlier marine incursions took place intermittently at least as long ago as Late Miocene time. These marine deposits have led to a continuing interest in the delta region 


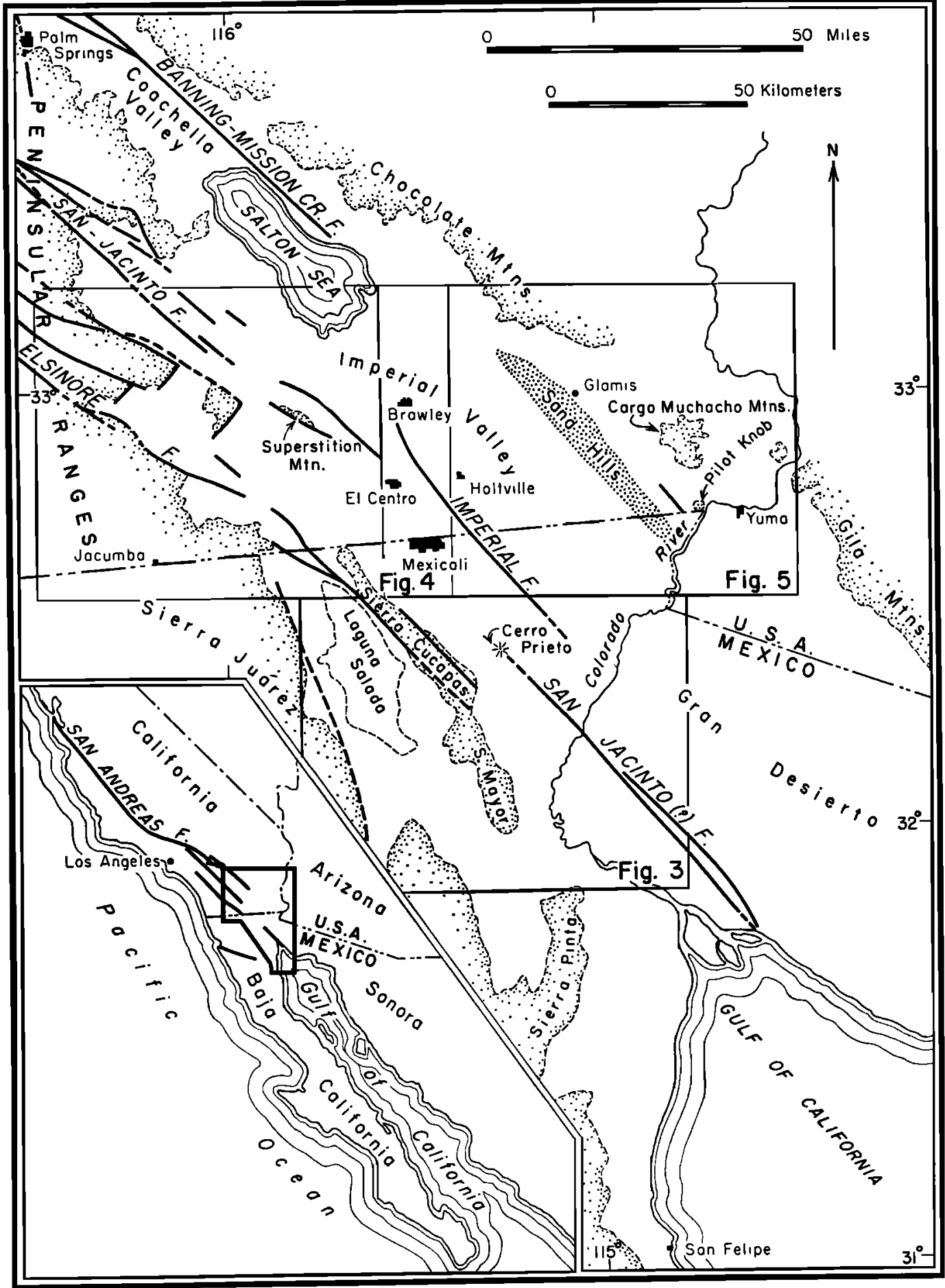

Fig. 1. Index map of the Colorado delta region showing locations of the major faults and locations of gravity maps. 
by oil companies, and a number of unsuccessful wells have been drilled.

Probably the best summary of the geology of the delta region north of the international border is that by Dibblee [1954]. Beal [1948] summarized what little is known of the geology in adjacent parts of Mexico.

\section{Sedimentary Rocks}

A composite stratigraphic section of the Cenozoic sedimentary rocks of the delta region is shown in Figure 2. It is important to note, however, that this section is based almost solely on limited exposures along the west side of the basin, where the section is turned up along bounding faults. Where concealed by alluvium in the central and eastern parts of the basin, the section may be very different for two primary reasons: (1) Major structural breaks such as the San Jacinto fault cut across many parts of the basin. Not only are some of these faults old enough to have strongly affected original depositional patterns, but there is also the distinct possibility of large post-depositional horizontal displacements along these faults. (2) Extremely abrupt facies changes take place even within the exposed parts of the section, and further facies changes toward the east are almost certain. For example, marine sediments to the west may interfinger with deltaic sediments of the Colorado River toward the east. Dry oil wells drilled to depths as great as 12,313 feet in the center of the basin have mainly penetrated beds thought to belong to the Borrego formation, although interpretation of the sparse paleontologic and stratigraphic data from these wells has been the subject of some controversy.

\section{Crystalline Rocks}

Pre-Tertiary rocks make up the northwest-

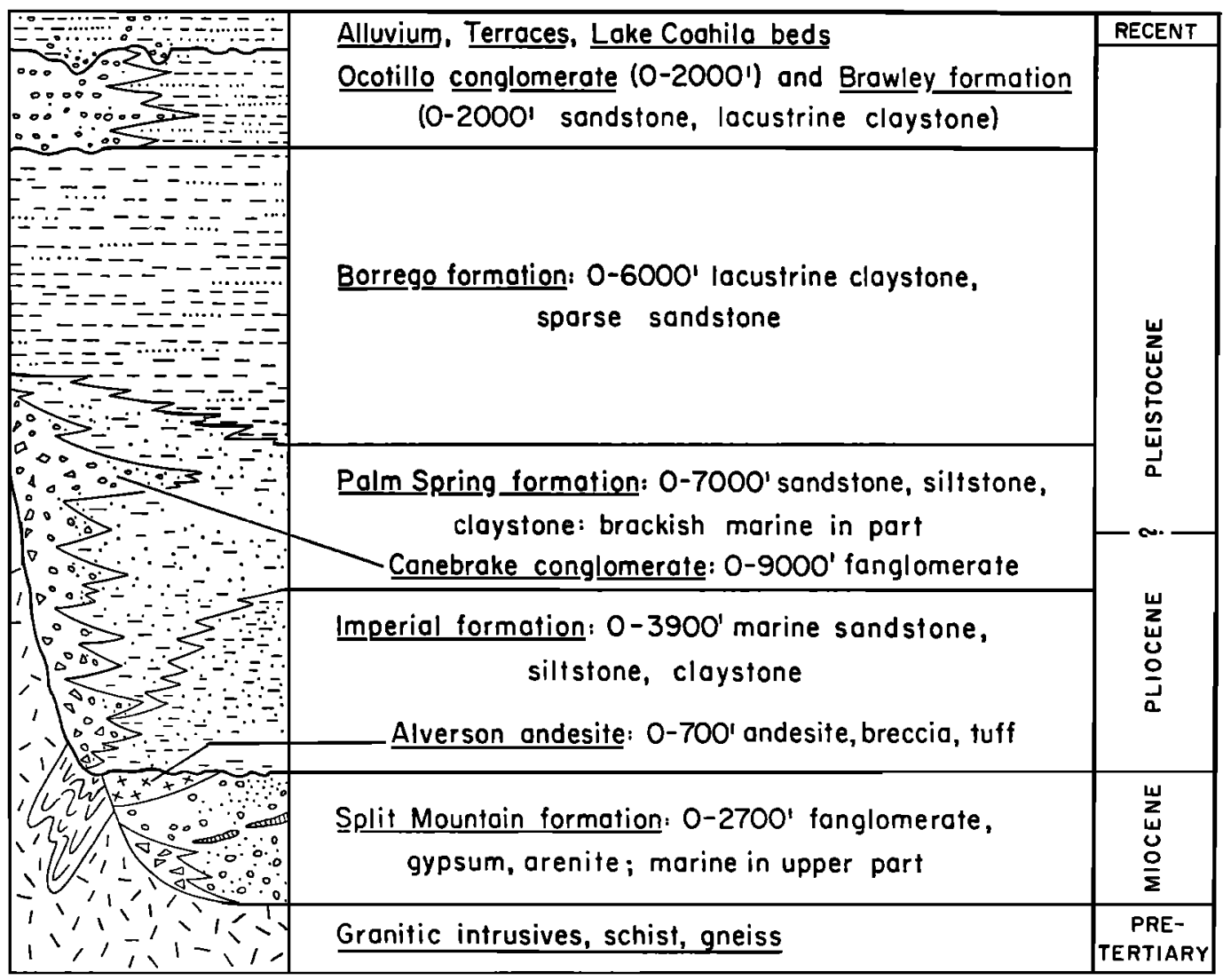

Fig. 2. Generalized stratigraphic column of the Colorado delta region, modified from Dibblee [1954]. 
trending mountain ranges on both flanks of the delta region (Fig. 1). On the southwest, the Peninsular Ranges and the Sierra Juárez are underlain by plutonic rocks of the great midCretaceous batholith of southern California and Baja California, together with prebatholithic metasedimentary and metavolcanic rocks [Larsen, 1948]. Fault slices within the basin, such as are represented by Superstition Mountain, suggest that similar rocks underlie much of the Imperial Valley as well. The northern part of the Sierra de los Cucapas is underlain by plutonic rocks, whereas the southern part is composed primarily of prebatholithic metasedimentary rocks including abundant quartzite and marble. Prebatholithic amphibolitic schists and Cenozoic volcanic rocks underlie the Sierra Pinta still farther south. Crystalline rocks on the northeast flank of the delta region have not been mapped in detail, but prebatholithic metasedimentary rocks appear to be dominant.

Cenozoic volcanic rocks overlie the older crystalline rocks in many areas on both sides of the delta region, and volcanic rocks such as the Miocene (?) Alverson Canyon andesite occur within the Cenozoic section of the basin itself. That volcanic activity has continued into Quaternary time is suggested by the well-preserved crater of Cerro Prieto, south of Mexicali (Fig. 1), and by the obsidian domes at the south end of the Salton Sea. The known presence of such intrusive and extrusive igneous rocks within the Cenozoic sedimentary section must be kept in mind as a possible complicating factor in geophysical interpretation.

\section{Faults}

The Colorado delta region lies essentially within the San Andreas fault zone, although it is not clear in this region which, if any, of the individual breaks within the zone should be called the San Andreas fault [Allen, 1957]. One of the hopes in the present stidy was to determine by geophysical means which of the faults of the delta region are the most persistent and throughgoing. The principal breaks known from surface mapping are the Banning-Mission Creek fault, the Imperial fault, the San Jacinto fault, and the Elsinore-Laguna Salada fault (Fig. 1).

The Banning-Mission Creek fault, often called the San Andreas fault in this area, is the most obvious active break in the northern part of the
Salton depression. However, no known surface expression of this fault extends past the southern end of the Salton Sea. Much speculation has arisen on the possible continuation of this break farther southeast, in part stimulated by the remarkably linear trend of the Sand Hills along the extended trace of the fault. Dibblee [1954] gave evidence of right-lateral displacement along the Banning-Mission Creek fault in the area of the Indio Hills.

The Imperial fault is marked by the line of displacement during the 1940 earthquake, but there is no other clear geological evidence of the fault. The break extended for 40 miles and showed right-lateral displacement throughout its length. A maximum slip of almost 20 feet was measured near the international border [Ulrich, 1941; Richter, 1958].

The San Jacinto fault is the straightest and possibly the most throughgoing member of the San Andreas system in southeastern California, although considerable branching obviously takes place along the west side of the Imperial Valley. A recent history of right-lateral displacement is indicated by prominent stream offsets along the fault where it crosses the Peninsular Ranges. Continuity of the San Jacinto fault into Mexico has not been established on the basis of surficial geology, although the well-exposed segment of this fault in California lines up remarkably well with the active break that cuts across the lower portion of the Colorado River delta in Mexico, as was first pointed out by Kniffen [1932]. Mexican aerial photographs taken in 1935, before cultivation of this portion of the delta, indicate a distinct and very linear Recent break extending for about 60 miles from Cerro Prieto into the Gulf of California (Figs. 1, 3). Other evidences of activity along this fault include numerous aligned hot springs and mud volcanoes, as well as earthquake epicenters. Indeed, the San Jacinto fault is the only break within the San Andreas fault zone in this region that is clearly delineated by a scries of moderate-sized earthquakes along most of its length during the past 50 years. The December 1934 earthquake ( $M=7.1$ ), centered on the San Jacinto (?) fault near Santa Clara Slough (Fig. 3), was probably associated with ground displacement along this segment of the fault, inasmuch as aerial photographs taken in 1935 show a fault scarp across the tidal flats of the lowcr delta 


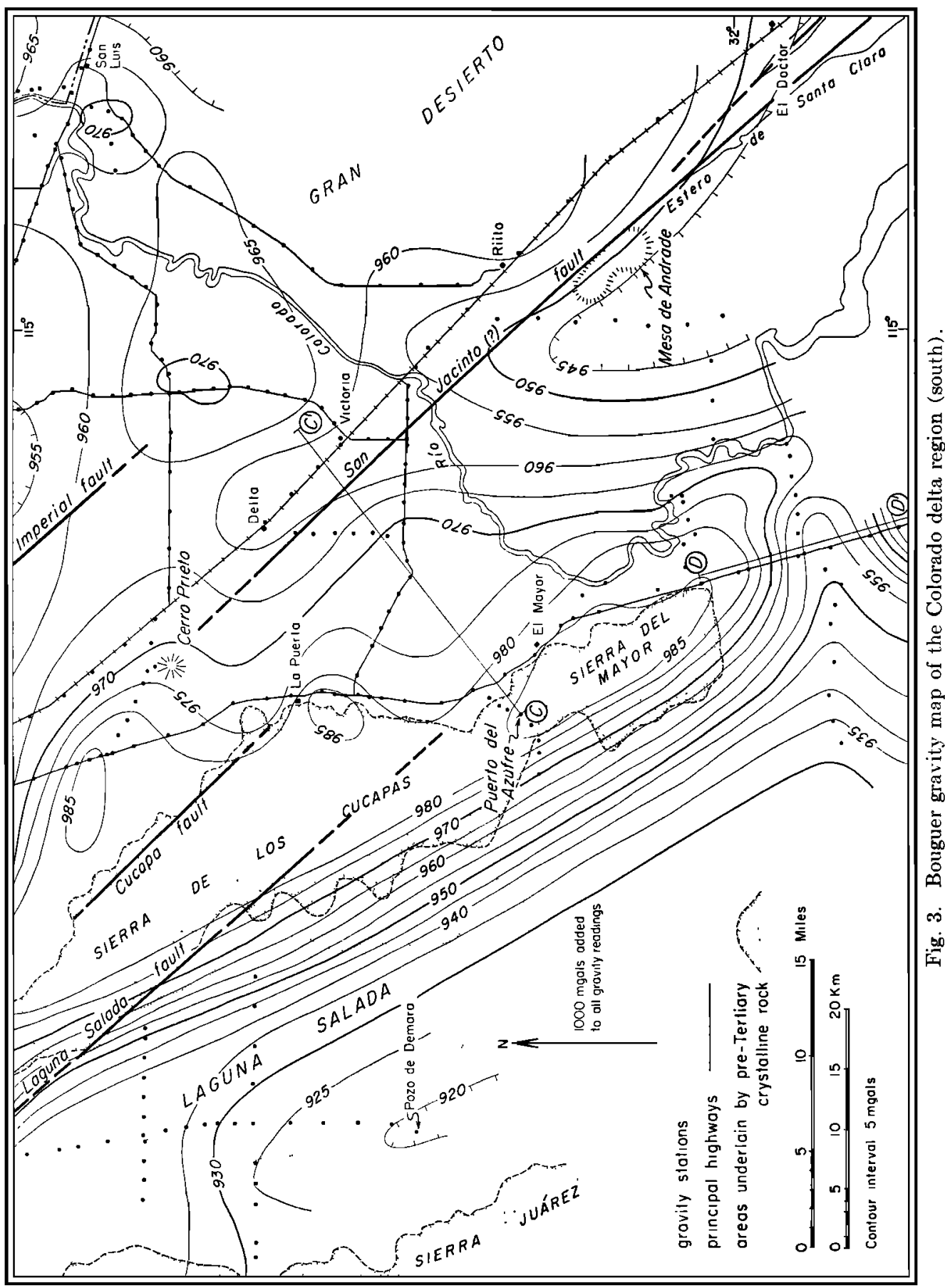




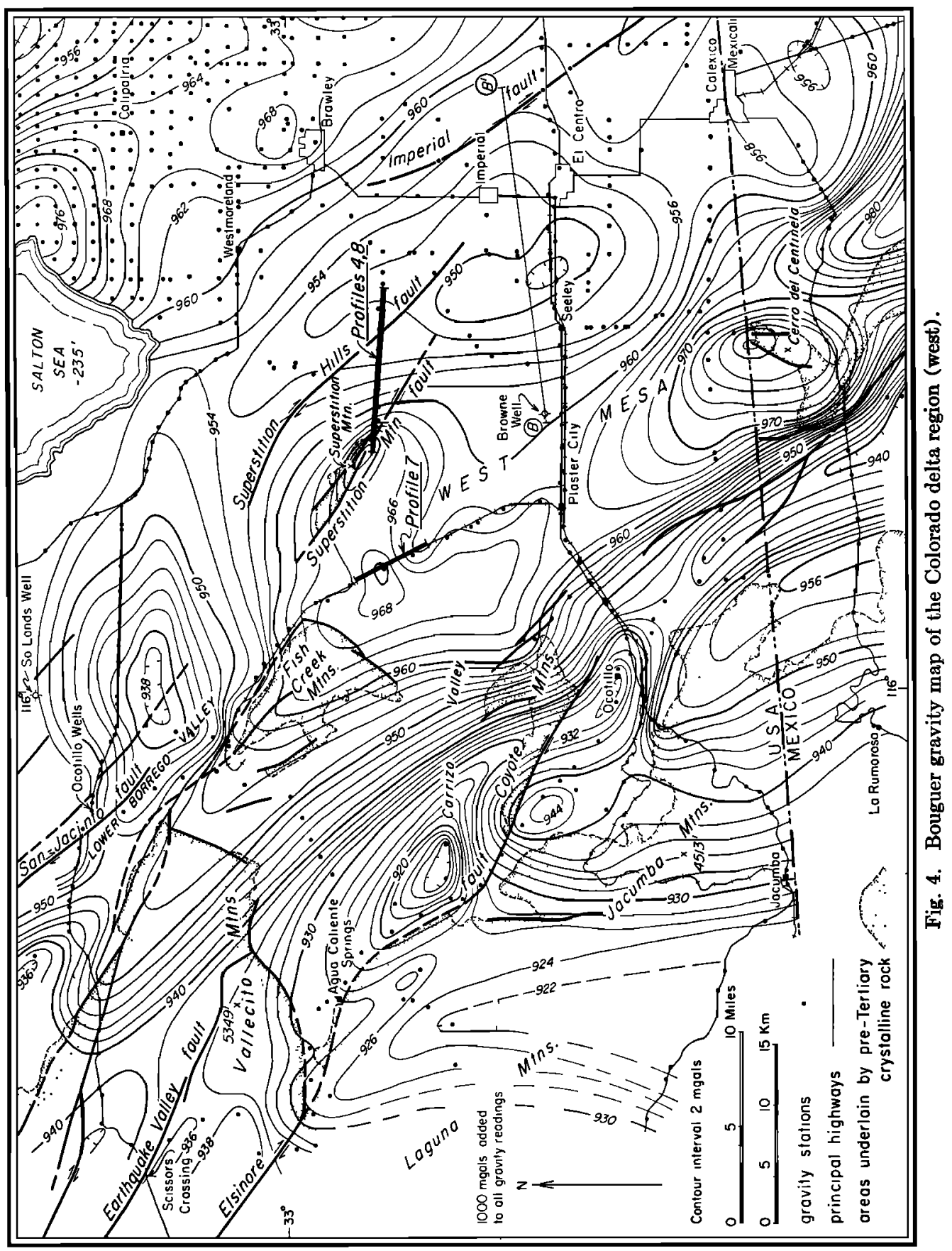




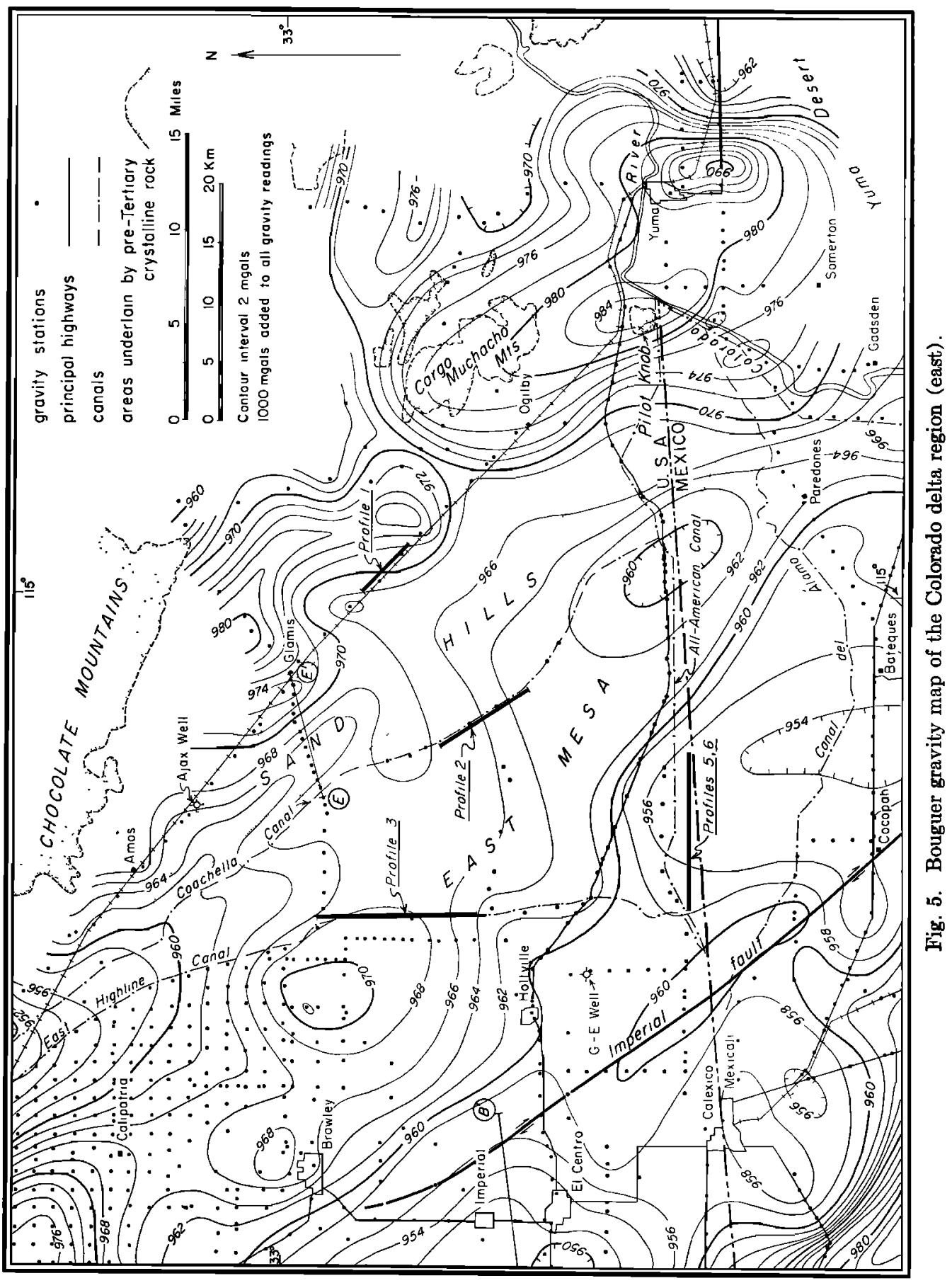


that appears very much fresher than it does in subsequent photographs of the same region.

The Elsinore fault forms the southwest margin of the San Andreas system in this region and has been mapped and described by Dibblee [1954]. The Laguna Salada fault appears to be the southern continuation of the Elsinore fault, and fresh scarps along the east side of Laguna Salada testify to Recent displacements on this break. Fault physiography suggests that the most recent break cuts southeastward across the Sierra de los Cucapas instead of continuing southward along the west margin of the range.

The fault along the northeast flank of the Sierra de los Cucapas, herein named the Cucapa fault, is characterized by a remarkable linear trench cutting continuously across the spurs at the margin of the range. The absence of Recent scarps within the trench suggests that it is caused by erosion of the highly fractured rocks within the fault zone rather than by Recent fault displacements. The linear and continuous eastern face of the Sierra Juárez, west of Laguna Salada, was recognized as a fault scarp by Lindgren [1888], but evidence for Recent move- ment on this fault is not abundant [Allen, Silver, and Stehli, 1960].

It is significant that none of these faults of the San Andreas system appears to curve southward so as to become truly parallel to the Gulf of California, as has been suggested by sketch maps of many previous authors. The BanningMission Creek fault, if extended, would continue into the Mexican mainland. Likewise the San Jacinto fault, if extended along the very linear trend evidenced by scarps in the delta region, would pass across the northeast corner of the Gulf and extend into Sonora. From the geological evidence available it thus appears more likely that the San Andreas system enters the Gulf of California as a series of great en échelon breaks rather than as a single curving fracture.

\section{Seismic Field Work and Reduction of Data}

Eight seismic refraction profiles were obtained in the Imperial Valley region. A method of refraction profiling was used which gives a rapid reconnaissance measurement of the seismic section. The method used was to keep the geophone spread fixed and to move the shot point away

TABLE 1. Velocities and Layer Thicknesses

\begin{tabular}{|c|c|c|c|c|c|c|c|}
\hline \multirow[b]{2}{*}{ Profile } & \multicolumn{7}{|c|}{ Velocities, $\mathrm{ft} / \mathrm{sec}$} \\
\hline & $V_{0}$ & $V_{1}$ & $V_{2}$ & $V_{3}$ & $V_{4}$ & $V_{s}$ & $V_{B}$ \\
\hline \multirow{7}{*}{$\left.\begin{array}{l}1 \\
2 \\
3 \\
4 W^{*} \\
8 E^{*} \\
5 E^{*} \\
6 W^{*} \\
7\end{array}\right\}$} & 3720 & & 6970 & & & & 18.520 \\
\hline & 2270 & 6270 & 7300 & 8770 & 11,050 & & 20.000 \\
\hline & 1200 & 5750 & 7620 & 8580 & 12,500 & & 18,180 \\
\hline & 1790 & 5650 & 7020 & 7920 & 10,700 & 14,200 & \\
\hline & 1500 & 6070 & 7580 & 8520 & 11,930 & 15,475 & \\
\hline & $(1500)+$ & & 0940 & & & & 19230 \\
\hline & \multicolumn{7}{|c|}{ Thicknesses, ft } \\
\hline Profile & $h_{0}$ & $h_{1}$ & $h_{2}$ & $h_{3}$ & $h_{4}$ & & $h_{\text {total }}$ \\
\hline 1 & 407 & & 1790 & & & & 2197 \\
\hline 2 & 77 & 1315 & 1450 & 2460 & 4070 & & 9372 \\
\hline 3 & 40 & 1426 & 3184 & 855 & 4645 & & 10,150 \\
\hline $4 W \ddagger$ & 65 & 595 & 1160 & 3473 & 3626 & & 8919 \\
\hline $8 \mathrm{E}^{+}$ & 33 & 809 & 1136 & 4416 & 2960 & & 9354 \\
\hline $5 E$ & 67 & 1520 & 1570 & 3935 & 4785 & & 11,877 \\
\hline $6 \mathrm{~W}$ & 32 & 1674 & 1770 & 3842 & 4222 & & 11,540 \\
\hline 7 & 134 & & 2620 & & & & 2754 \\
\hline
\end{tabular}

* $E$ and $W$ signify east or west ends of reversed profile.

$\dagger(1500)$ denotes assumed velocity.

$\ddagger$ Thickness computed under shot point 10 . 
from the spread. The apparent velocity of a refracted arrival across the spread is then compared with the apparent velocity obtained from the travel times from two or more shots to one of the geophones. This method of refraction shooting gives true reversal information provided that there are no dip reversals or complicated structures between the shot point and the geophone spread. A dipping bed is recognized by an en échelon pattern or 'shingling' of arrivals on the time-distance graph.

Shot holes were drilled to an average depth of 60 feet. However, it was found, particularly on the east side of the Imperial Valley, that excellent seismic records could be obtained with small charges placed in hand-drilled holes 5 feet below the surface. In this region, when shooting was done near canals, the water table was about 5 feet below the surface in sandy material, and excellent energy coupling was obtained. The size of the charge used was extremely variable, but it was generally found for shot-to-detector distances greater than about 6 miles that 30 to 50 $\mathrm{lb}$ of explosive were necessary.

\section{Setsmic Refraction Propiles}

The location of the seismic profiles is shown on the gravity maps (Figs. 4 and 5), and the results are summarized in Table 1 . Sample seismograms from profile 6 are shown in Figure 6. Figures 7 to 12 show the travel-time graphs and deduced seismic sections.

Profile 1 (Fig. 7). This profile was shot along the Ogilby-Glamis road on the east side of the Sand Hills (Algodones dunes). The depth to basement is about 2200 feet. The 6970 -ft/sec layer gave a very strong arrival on the seismograms which persisted as a strong second arrival. The absence of sedimentary velocities greater than $6970 \mathrm{ft} / \mathrm{sec}$ probably indicates that a substantial

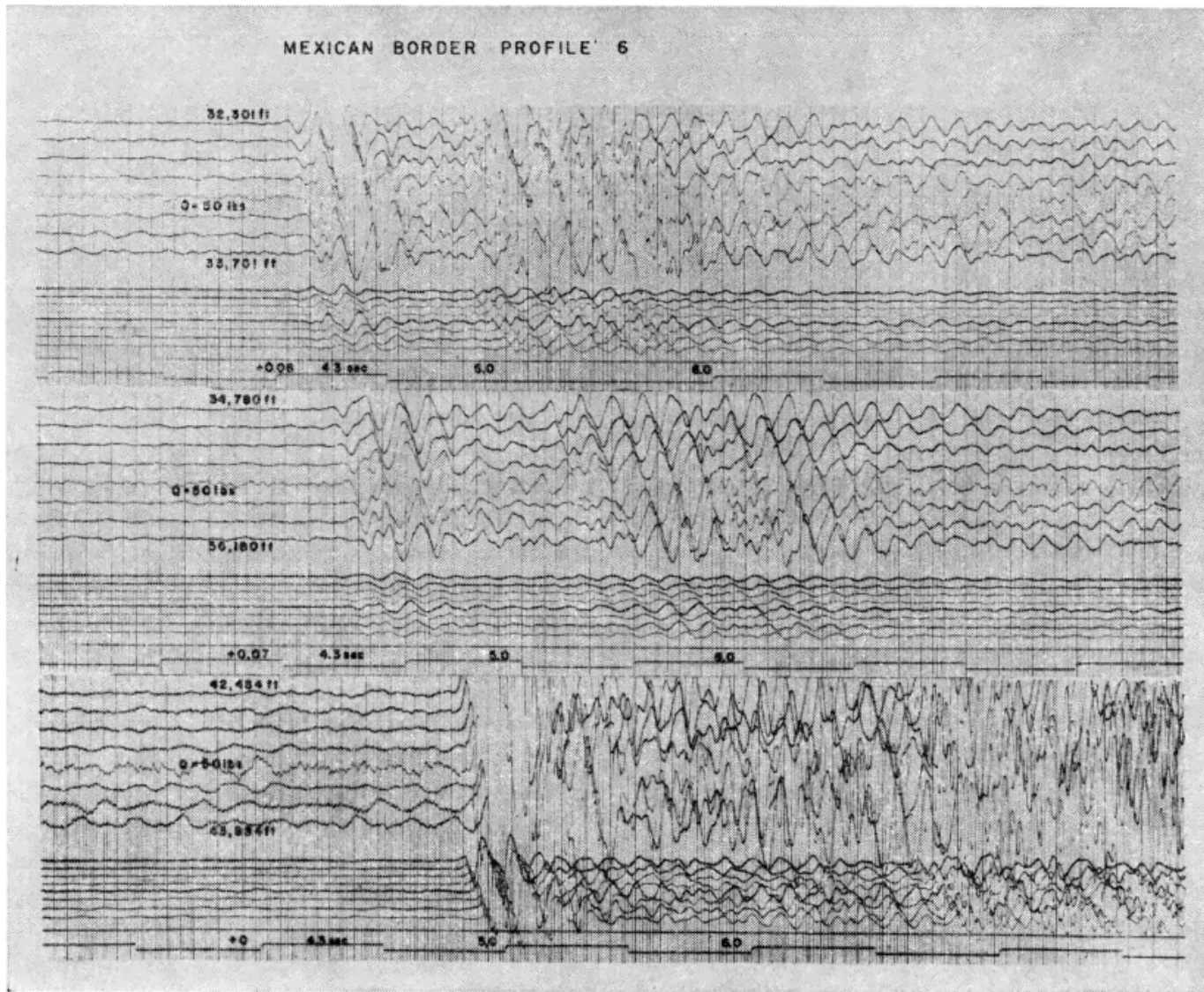

Fig. 6. Sample seismograms from profile 6 . 


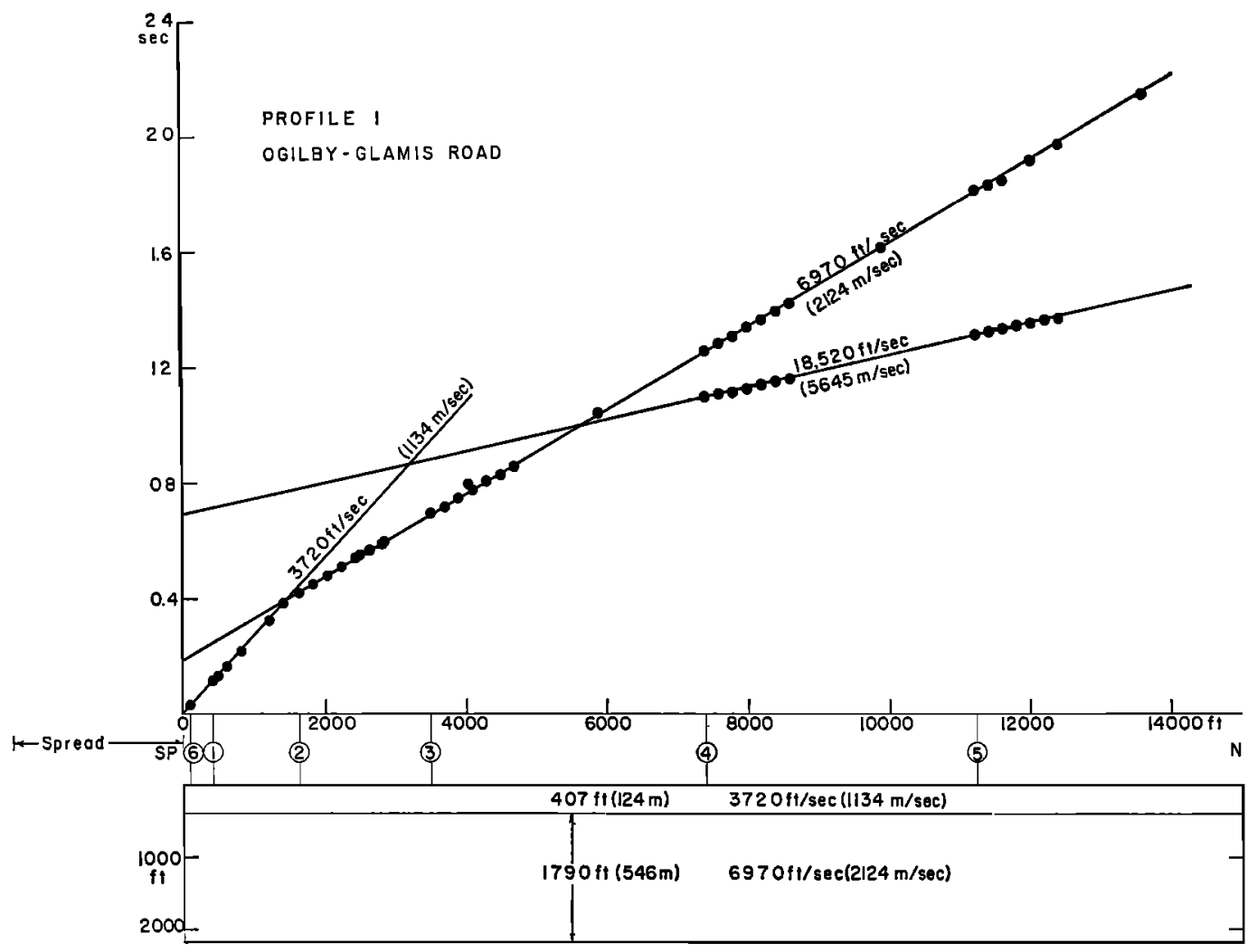

$18,520 \mathrm{f} 1 / \mathrm{sec}(5645 \mathrm{~m} / \mathrm{sec})$

Fig. 7. Seismic profile 1.

portion of the Cenozoic section present elsewhere in the valley is absent in this region.

Profile 2 (Fig. 8). This profile was shot along the Coachella canal on the west side of the Sand Hills. The depth to basement is about 9370 feet. Below the $6270-\mathrm{ft} / \mathrm{sec}$ layer are three layers with velocities of 7300,8770 , and $11,050 \mathrm{ft} / \mathrm{sec}$ within the Cenozoic section. An alternative interpretation would be to combine the $7300-\mathrm{ft} / \mathrm{sec}$ layer with the 8770-ft/sec layer. However, this interpretation gives an almost identical depth to basement to that determined with the $7300-\mathrm{ft} /$ sec layer present. A comparison of the basement depths between profiles 1 and 2 shows the rapid deepening of basement across the Sand Hills.

Profile 3 (Fig. 9). This north-south profile is located along the East Highline canal on the eastern margin of the cultivated area of the Imperial Valley. Below the weathered layer the arrivals show layers with velocities of 5750 , 7620,8580 , and $12,500 \mathrm{ft} / \mathrm{sec}$. The $8580-\mathrm{ft} / \mathrm{sec}$ arrival was not present as a first arrival and is only an average apparent velocity, since the first motion was very difficult to measure. Neglecting the presence of the $8580-\mathrm{ft} / \mathrm{sec}$ layer has only a negligible effect on the calculated depth to basement. Because of the importance of obtaining an accurate measurement of the depth to the basement, this profile was shot to a distance of over 44,000 feet to be certain that the $18,000-\mathrm{ft} /$ sec arrival was definitely a basement arrival. The depth to basement is 10,050 feet. Very strong second arrivals having an apparent velocity of $7620 \mathrm{ft} / \mathrm{sec}$ are also present and are shown on the travel-time graph. Since this second arrival has twice the intercept time of the $7620-\mathrm{ft} / \mathrm{sec}$ layer as a first arrival, it is identified as a double refraction of the $7620-\mathrm{ft}$ / sec layer.

The Texas Company's Grupe-Engebretson well, located south of Holtville, California, was velocity surveyed to 7827 feet. This well had a 


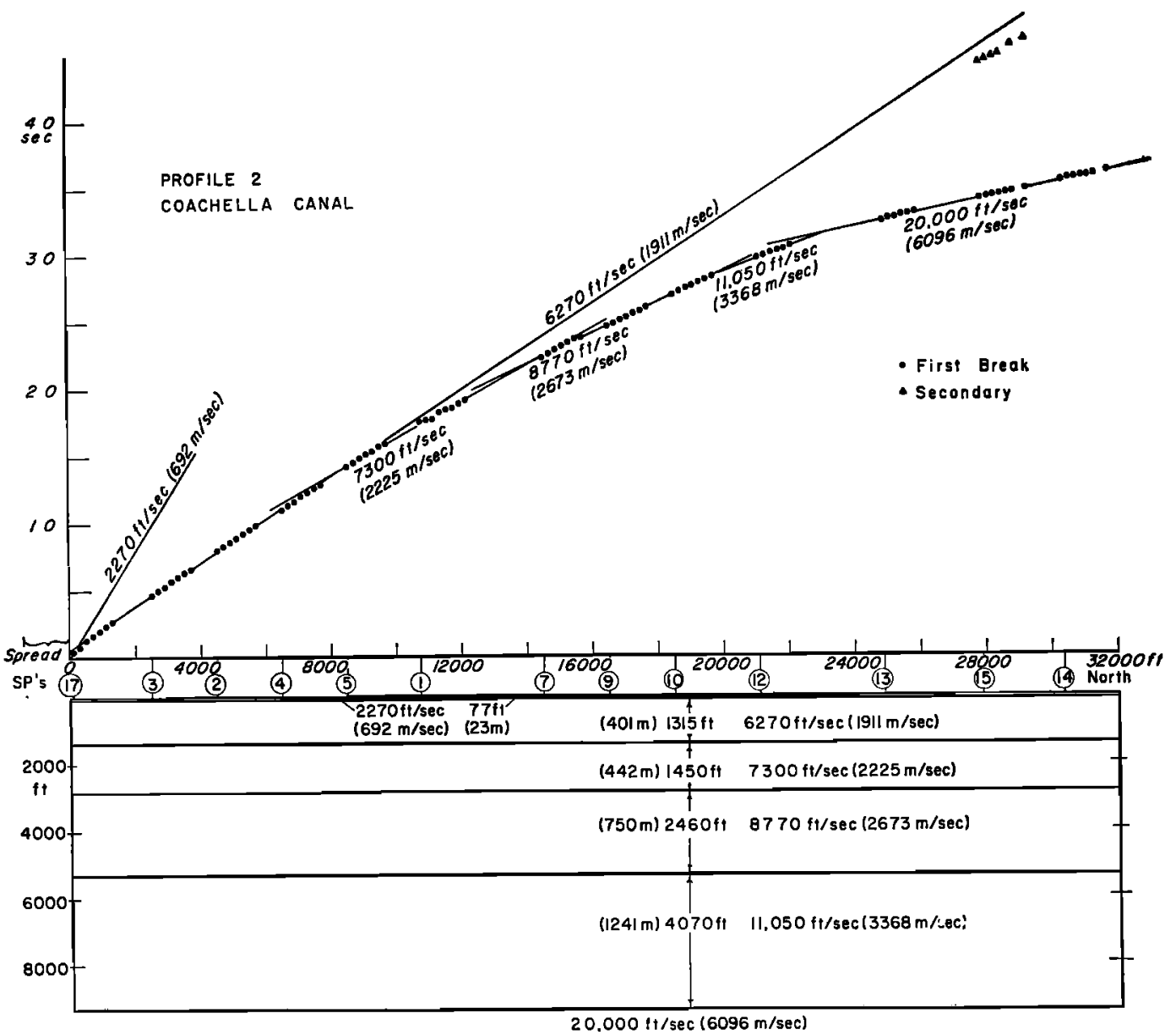

Fig. 8. Seismic profile 2.

surface velocity of $1000 \mathrm{ft} / \mathrm{sec}$ and then 'broke' into a 5230-ft/sec layer. The interval velocities ranged from 6580 to $15,625 \mathrm{ft} / \mathrm{sec}$, and two small velocity reversals with depth were found. A velocity-depth function of $V=5777+$ $0.652 D$ was determined from the interval velocity log. Using this velocity-depth function it is possible to compute a refraction travel-time curve from the relation $T=(2 / 0.652) \sinh ^{-1}$ $(0.652 X / 11,554)$ where $T$ is the time in seconds and $X$ is the source to detector distance in feet [Dix, 1952, p. 248]. As shown in Figure 9, the refraction data agree well to a depth of $\mathbf{5 5 0 0}$ feet but deviate strongly at the $12,500-\mathrm{ft} / \mathrm{sec}$ layer from this computed travel-time curve based on a linear increase with depth for the velocity. However, it should be pointed out that the Grupe-Engebretson well is located about 3 miles southeast of this profile and that a 12,500 $\mathrm{ft} / \mathrm{sec}$ velocity was not identified in the well velocity survey. From 2800 feet to the bottom of the Grupe-Engebretson well were various rock types, all reportedly belonging to the Borrego formation. Since the wide range of velocities measured in this well was thought to be within this formation, it would not be profitable to attempt to assign stratigraphic horizons to the velocities revealed by the refraction measurements. Furthermore, a wide range of velocities is often determined for similar rocks, and similar velocities are often determined for widely different lithologies. However, the abrupt velocity change to $12,500 \mathrm{ft} / \mathrm{sec}$ indicated from the refraction data may be related to sediments of some stratigraphic significance that were not penetrated in the Grupe-Engebretson well. 


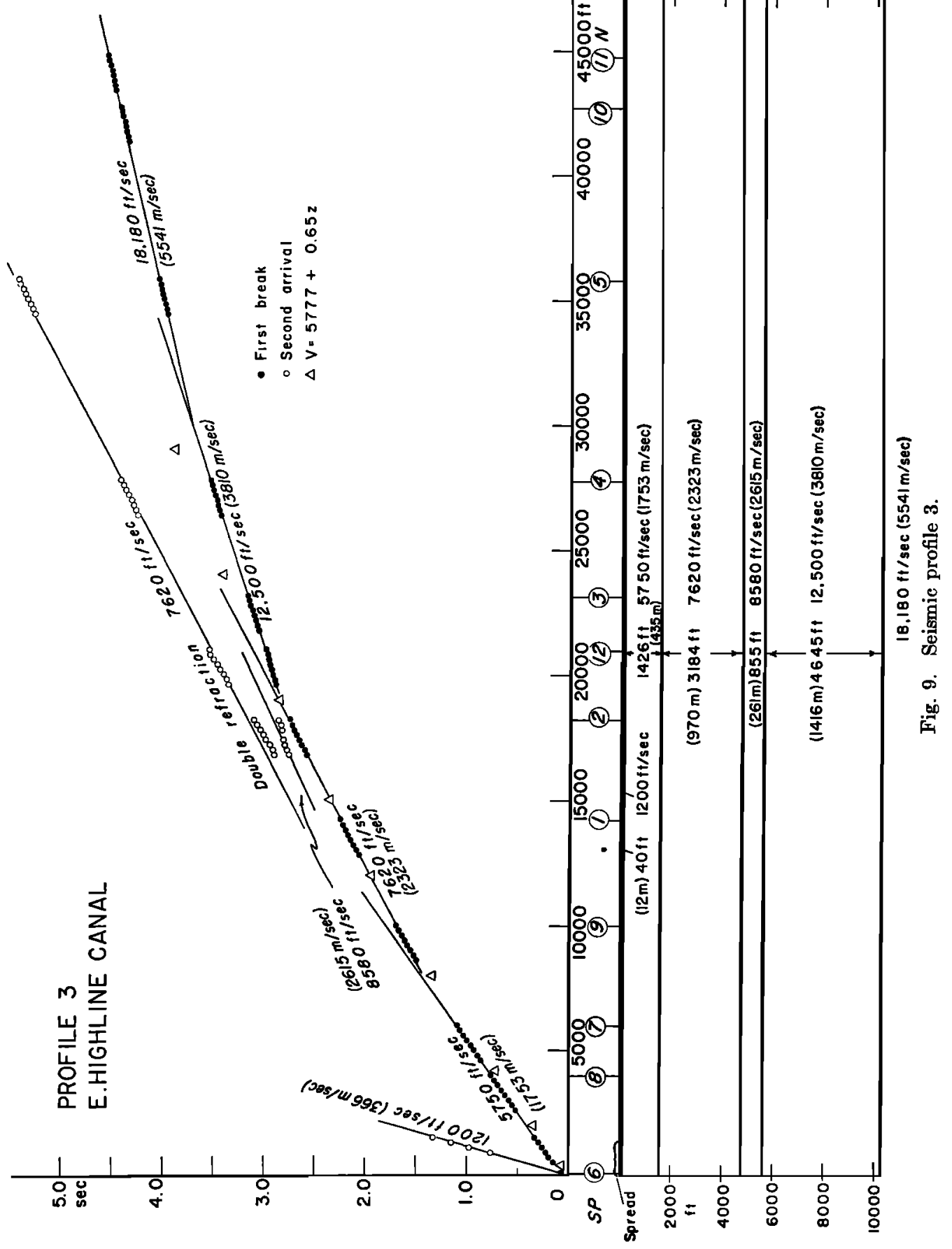




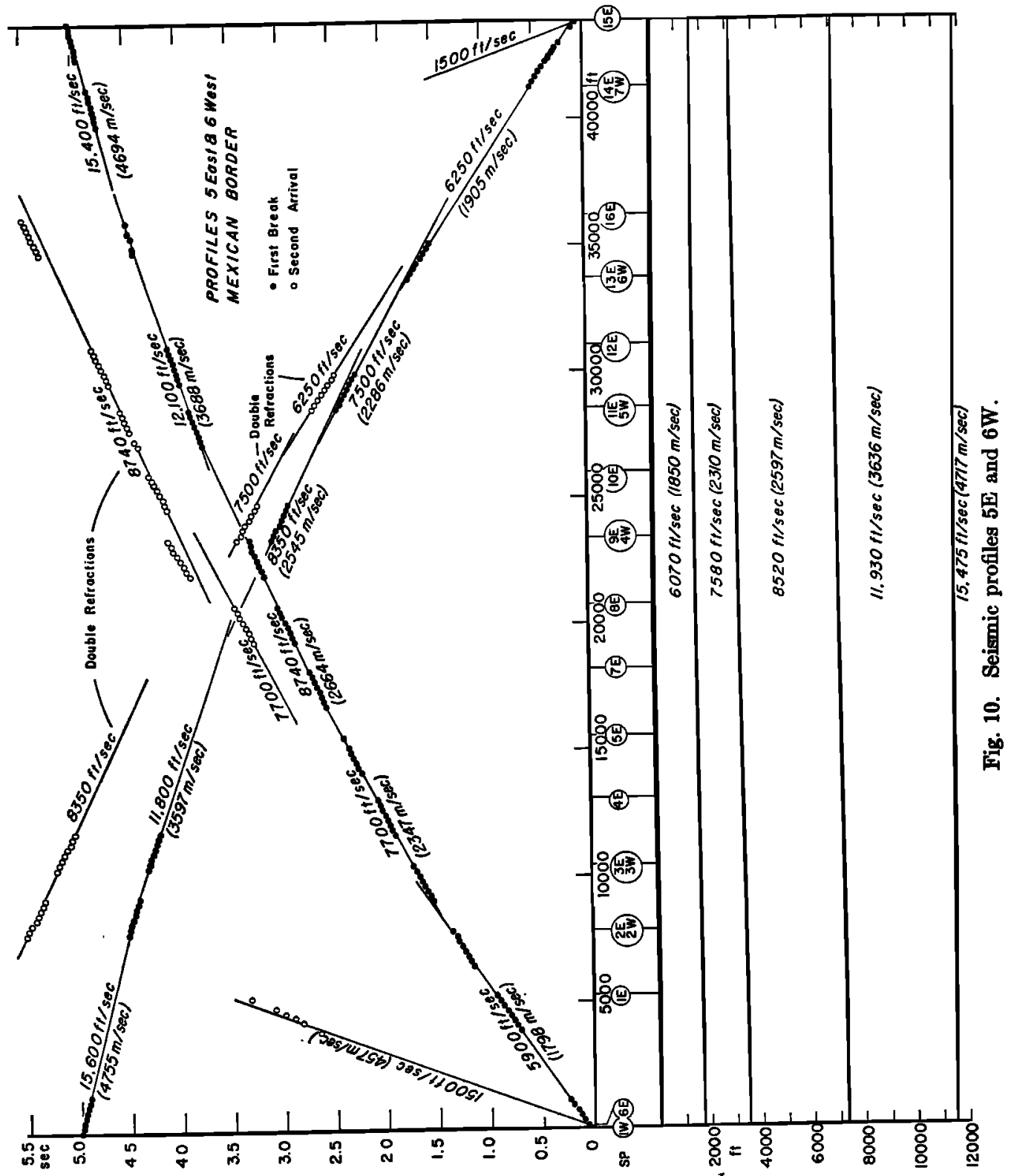




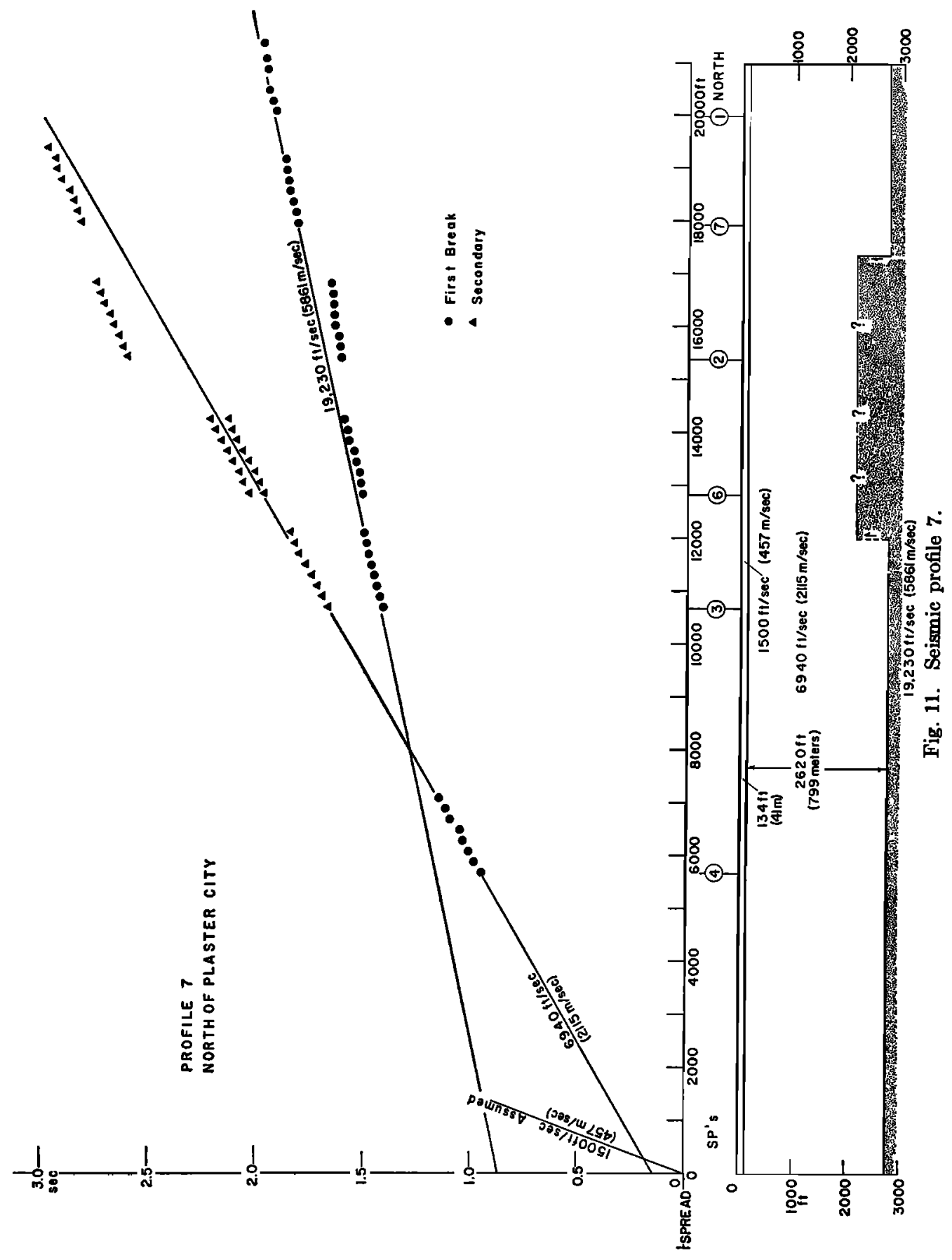




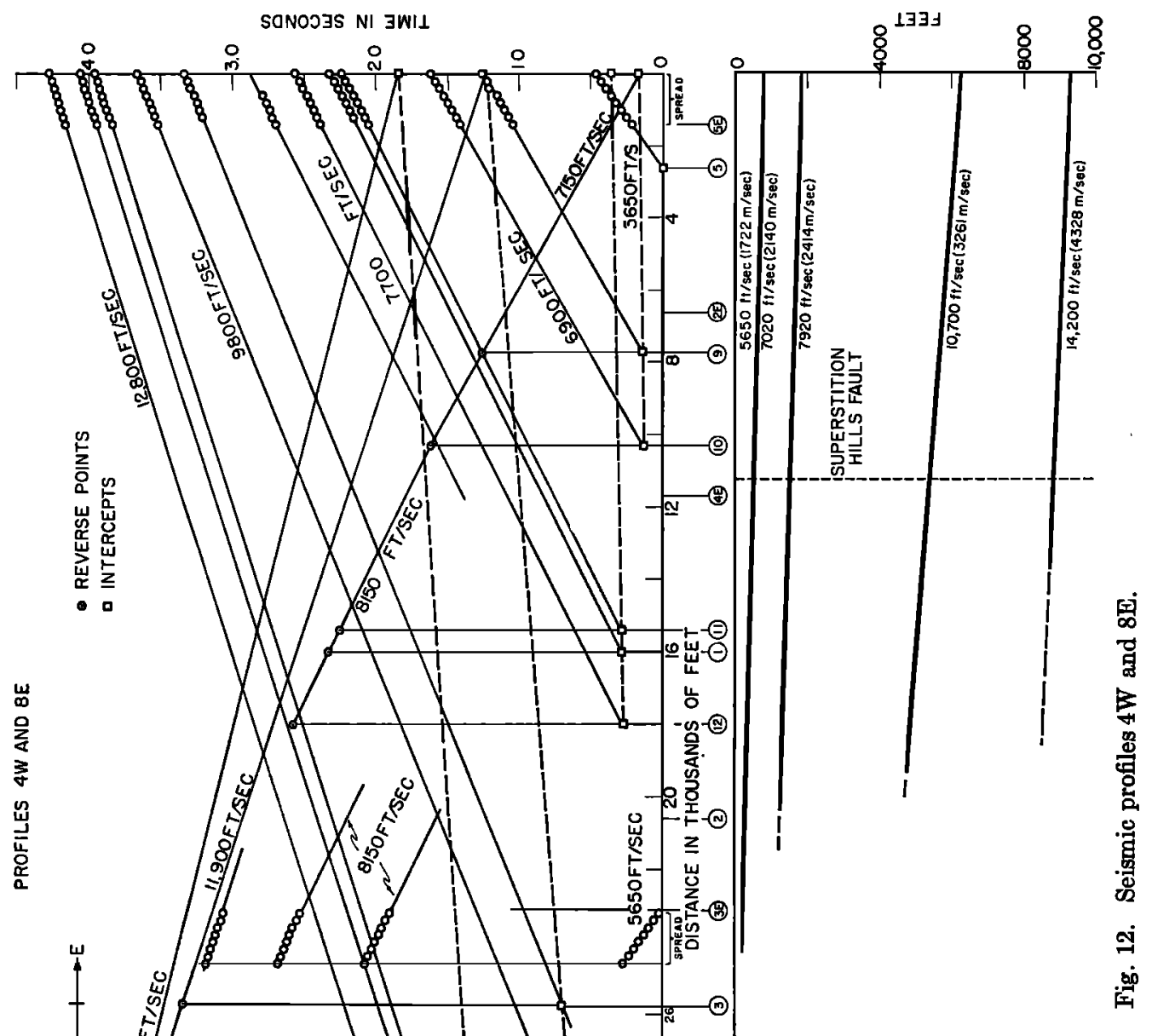


Profiles $5 E$ and $6 W$ (Fig. 10). These two eastwest profiles form one completely reversed refraction profile. This profile is located directly south of profile 3 and is about $1 / 2$ mile north of the international boundary. The average velocities measured are 6070, 7580, 8520, 11,930, and $15,475 \mathrm{ft} / \mathrm{sec}$, almost negligible dip being indicated for the refracting horizons. Strong second arrivals were present on many of the seismograms, but all were identified as double refractions. The total length of this refraction line was about 8.5 miles, yet only a velocity of $15,475 \mathrm{ft} / \mathrm{sec}$ was reached. The depth to the 15 ,$475-\mathrm{ft} / \mathrm{sec}$ layer is about 11,600 feet, and the question is immediately raised whether this 15 ,475-ft/sec arrival is a basement arrival. It is believed that this is not an arrival from the basement, since $15,475 \mathrm{ft} / \mathrm{sec}$ is low compared with the 18,000 - to $20,000-\mathrm{ft} / \mathrm{sec}$ basement velocity measured elsewhere in the delta region. Assuming that the basement velocity is $18,000 \mathrm{ft}$ / sec and that the velocity immediately breaks into a basement arrival at the most distant point on the travel-time graph, the minimum depth to basement is about 15,400 feet under this profile.

Profile 7 (Fig. 11). This north-south profile was shot along the right-of-way of the private railroad of the Portland Cement Company. Because of field difficulties, no near-spread shots were fired. A surface layer of velocity $1500 \mathrm{ft} /$ sec was assumed to account for the failure of the $6940-\mathrm{ft} / \mathrm{sec}$ layer to have a zero intercept. The depth to basement is about 2750 feet. The offset in the basement arrival is interpreted as an uplifted fault block in the basement or a small basement high. The approximate vertical displacement, $Z$, may be computed from the relation $Z=\Delta t V_{1} V_{2} /\left(V_{2}^{2}-V_{1}^{2}\right)^{1 / 2}$ [Nettleton, 1940 , p. 2737 . With $\Delta t=0.08$ sec, $V_{1}=6940$ $\mathrm{ft} / \mathrm{sec}$, and $V_{2}=19,230 \mathrm{ft} / \mathrm{sec}, Z$ is approximately 600 feet. A small gravity high of about 5 mgal is found over this basement high. The offset in the basement arrival could alternatively be explained with a single fault in the basement using a basement velocity greater than 19,230 $\mathrm{ft} / \mathrm{sec}$ to fit the data.

Profiles $8 E$ and $4 W$ (Fig. 12). These two eastwest profiles form one partially reversed refraction profile in the Superstition Hills area. Because of the sloping terrain between the shot points and the detector, all travel times were reduced to a datum of 100 feet below sea level using a technique described by Nettleton [1940, p. 301]. This correction reduced the observed travel times as if the surface low-velocity layer $(1790 \mathrm{ft} / \mathrm{sec})$ were not present. Since a plot of the data on a conventional travel-time graph showed an en échelon pattern indicating dipping interfaces, the shot point and the first geophone were interchanged to obtain the maximum amount of reversal information. Profile $4 \mathrm{~W}$ was used to confirm the apparent velocities in the east-to-west direction.

Beneath the unconsolidated surface sediments, average velocities of $5650,7020,7920,10,700$, and $14,200 \mathrm{ft} / \mathrm{sec}$ were measured. Approximately a $2^{\circ}$ to $4^{\circ}$ easterly dip is indicated for the refracting horizons. Exceptional efforts were made to obtain basement arrivals by extending this refraction line to 44,000 feet ( 8.5 miles). Charges were placed at a depth of 60 feet in the basement complex of the Superstition Mountains, located 44,000 feet west of the east geophone spread. Even though large charges were fired $(50 \mathrm{lb})$, no detectable arrivals were received at the geophone spread. If we assume that the basement velocity is $18,000 \mathrm{ft} / \mathrm{sec}$, the minimum depth to basement under the east spread is about 11,400 feet. No large offisets in the traveltime data are observed crossing the Superstition Hills fault, and so it is believed that large vertical displacement is not present on the Superstition Hills fault in this region.

\section{Gravity Field Work and Reduction of Data}

Approximately 1250 gravity observations were made in the United States and Mexico. The gravity observations are tied to a network of gravimeter base stations in the Imperial Valley which, by a succession of stations, are tied to the USCGS pendulum station in Pomona, California [Duerksen, 1949]. Elevations of stations in the United States were obtained from survey bench marks, level survey lines, and altimeter readings; a few station elevations were estimated from topographic maps. In Mexico, gravimeter base stations were established on bench marks of the International Boundary and Water Commission. The elevations of the remainder of the gravity stations in Mexico were determined by altimeter. The possible elevation error in Mexico is estimated to be 15 feet. Horizontal location of the gravity stations in the 
United States is probably within 50 feet; in Mexico, because of the inadequate maps available, some of the remote stations in the Laguna Salada area may conceivably be in error by as much as $\mathbf{1 0 0 0}$ feet of horizontal distance. However, the majority of the stations in Mexico are probably located to within $\mathbf{5 0 0}$ feet of horizontal distance. The gravity observations were corrected for drift, elevation, and latitude by conventional techniques. Considering all these factors, the precision of the Bouguer gravity anomalies in the United States is estimated to be $0.3 \mathrm{mgal}$; in Mexico the precision is estimated to be $1 \mathrm{mgal}$, although some stations could be in error by more than $1 \mathrm{mgal}$.

An elevation factor of $0.069 \mathrm{mgal} /$ foot was used, corresponding to a roek density of 2.00 g/cm". For stations above 1000 feet in elevation an elevation factor of $0.069 \times 1000+0.060(h$ - 1000) was used, where $h$ is the station elevation in feet. 1000 feet is the average elevation at which basement crops out in the Peninsular Ranges. This correction was used for 25 gravity stations, shown on the eastern extremity of Figure 4. An elevation factor of $0.060 \mathrm{mgal} / \mathrm{foot}$ corresponds to a rock density of $2.67 \mathrm{~g} / \mathrm{cm}^{3}$. All gravity stations were reduced to a sea level datum. In the United States, terrain corrections were made for most of the stations out through zone $\mathrm{H}$ (8578 feet) using the terrain correction tables of Hammer [1939]. Trial terrain corrections for a few stations were carried out through zone M (71,996 feet) but these corrections did not significantly alter the gravity picture. Terrain corrections were not made for the gravity stations in Mexico because of the lack of topographic maps. Since most of the stations in Mexico are in the broad alluviated delta region, failure to make terrain corrections does not have a significant effect on the majority of the stations. Near the Sierra de los Cucapas and the eastern front of the Sierra Juárez, failure to make terrain corrections could conceivably introduce errors of as much as $3 \mathrm{mgal}$. The Bouguer gravity anomalies for stations near the Cucapas would be raised relative to the values of the stations located in the flat alluviated areas.

Gravity values were reduced to the complete Bouguer anomaly with respect to the International Ellipsoid. 1000 mgal was added to the gravity values so that the gravity contours on the map would all be positive.

\section{Density}

Rock densities for the Colorado delta region, obtained from various unpublished sources, are summarized in Table 2.

For purposes of interpretation, a representative density of $2.67 \mathrm{~g} / \mathrm{cm}^{3}$ is given to the preTertiary rocks. Because of the extreme heterogeneity of the Cenozoic sedimentary deposits it is very difficult to assign a representative density to these deposits. Because it is recognized that densities determined from surface outcrop samples can be misleading and no account of probable compaction of the sediments with depth is taken, a mean density of $2.40 \mathrm{~g} / \mathrm{cm}^{8}$ is assigned to the Cenozoic deposits in areas where no other control exists.

TABLE 2. Rock Densities

\begin{tabular}{|c|c|c|c|}
\hline Rock & $\begin{array}{l}\text { No. of } \\
\text { Samples }\end{array}$ & $\begin{array}{c}\text { Density } \\
\text { Range,* } \\
\text { g/cm }\end{array}$ & $\begin{array}{c}\text { Average } \\
\text { Density, } \\
\text { g/cm }\end{array}$ \\
\hline \multicolumn{4}{|l|}{ Surficial Samples } \\
\hline $\begin{array}{l}\text { Plutonic and } \\
\text { metamorphic } \\
\text { rocks }\end{array}$ & 33 & $2,40-2,92$ & 2.67 \\
\hline $\begin{array}{l}\text { Plutonic and } \\
\text { metamorphic }\end{array}$ & & & \\
\hline $\begin{array}{r}\text { rocks } \dagger \\
\text { Tertiary }\end{array}$ & 24 & $2.58-2.78$ & 2.68 \\
\hline sediments & 23 & $1.85-2.57$ & 2.33 \\
\hline $\begin{array}{l}\text { Borrego fm. } \\
\text { Palm Spring }\end{array}$ & 3 & $2.18-2.57$ & 2.34 \\
\hline fm. & 5 & $2.14-2.56$ & 2.35 \\
\hline $\begin{array}{l}\text { Imperial fm. } \\
\text { Recent }\end{array}$ & 5 & $1.85-2.43$ & 2.26 \\
\hline siltstones & 2 & $2.17-2.28$ & 2.23 \\
\hline $\begin{array}{l}\text { Tertiary } \\
\text { volcanic flows }\end{array}$ & 2 & & 2.61 \\
\hline $\begin{array}{l}\text { Tertiary } \\
\text { volcanic } \\
\text { flows } \dagger\end{array}$ & 4 & $2.50-2.79$ & 2.68 \\
\hline Obsidian & & & \\
\hline buttes & 1 & & 2.32 \\
\hline Well samples & & & \\
\hline $\begin{array}{l}\text { (Samples } \\
\text { from } 5 \text { wells) } \\
0-4000 \mathrm{ft}\end{array}$ & & & \\
\hline depth & 8 & $2.06-2.66$ & 2.37 \\
\hline $4000-8000 \mathrm{ft}$ & 15 & $2.23-2.57$ & 2.44 \\
\hline $8000-12,000 \mathrm{ft}$ & 4 & $2.35-2.59$ & 2.47 \\
\hline
\end{tabular}

* All densities are saturated bulk densities unless otherwise noted.

† Denotes bulk dry density. 
It is recognized, however, that the density contrast may vary from -0.4 to $-0.2 \mathrm{~g} / \mathrm{cm}^{2}$ owing to the variability of the densities of the Cenozoic deposits, known density reversals with depth within the Borrego formation, and a general increase of density with depth.

\section{Gravity Contour MaP}

The Bouguer gravity anomaly maps are shown in Figures 3, 4, and 5. A casual inspection of the Bouguer gravity field shows that the over-all trend of the isogal contours is northwesterly, in agreement with the over-all trend of the tectonic features in the region. The Bouguer gravity anomalies range from 990 to $912 \mathrm{mgal}$. Since the gravity values on basement outcrops at Signal Mountain, at the Superstition Mountains, and at Pilot Knob are approximately equal, the east-west regional gradient is zero within the area bordered by these basement outcrops.

By far the dominant feature of the Bouguer gravity field in Mexico (Fig. 3) is the steep gravity gradient present on the west side of the Sierra de los Cucapas. It is undoubtedly partially associated with the Laguna Salada fault, located on the west side of the Cucapas. From the indicated steepness of this gravity gradient ( $7 \mathrm{mgal} / \mathrm{mile}$ ) the interface between the sediments of Laguna Salada and the basement rocks of the Cucapas is probably vertical or dips steeply. This zone of gravity gradient can be followed into the United States (Fig. 4) to the Elsinore fault, which is also well defined by a steep gravity gradient zone. Thus, it is believed that the Laguna Salada fault is the southern continuation of the Elsinore fault.

Toward the center of the Imperial Valley the average Bouguer anomaly is only about -12 to -20 mgal relative to bedrock areas at the Superstition Mountains and at Signal Mountain. It is difficult to reconcile these values with sedimentary thicknesses alone, using calculations with a single sediment-basement density contrast. Regardless of what density contrast is selected within the broad range of -0.2 to -0.5 $\mathrm{g} / \mathrm{cm}^{\mathrm{s}}$, an incorrect basement depth is obtained. For example, the gravity relief between Signal Mountain (Cerro del Centinela) and seismic profiles 5 and 6, along the Mexican border, is about $22 \mathrm{mgal}$. If we estimate the basement depth using this local anomaly and a contrast of
$-0.2 \mathrm{~g} / \mathrm{cm}^{\mathrm{s}}$, we obtain 8500 feet as the thickness of sediments; yet seismic profile 5 indicates a minimum depth to basement of 15,400 feet. Samples of the sediments from the nearby Grupe-Engebretson well showed a density of $2.50 \mathrm{~g} / \mathrm{cm}^{\mathrm{a}}$ at a depth of 7000 feet and a density of $2.59 \mathrm{~g} / \mathrm{cm}^{2}$ at a depth of about 11,300 feet. Furthermore, a density reversal was present in the depth interval of 8000 to 10,000 feet. We are thus led to believe that the observed Bouguer anomaly in the center of the basin is affected by density contrasts within the Tertiary section, rather than by a sediment-basement density contrast only. This result is not unexpected in deep and large sedimentary basins where there is an increase of density with depth within the sedimentary column because of compaction, so that the deeper sediments have in situ densities very close to basement densities [Woollard, 1953; Tsuboi, 1956; Vyskočil, 1956].

Another possible explanation of the failure of gravity measurements to explain the thickness of sediments in Imperial Valley is that isostatic compensation beneath the deepest part of the valley causes local warping of the regional gradient. Failure to apply such an isostatic correction would lead to underestimation of sediment thickness. That crustal thinning does indeed take place beneath the Gulf of California has been shown by Shor $[1959,1962]$, and tectonic implications of this have been discussed by Hamilton [1961]. But whether such crustal thinning could significantly affect the gravity interpretation in a basin as narrow as the Imperial Valley depends on the nature and localization of the isostatic compensation. Under the extreme assumption of a sharp notch in the base of a normal $32-\mathrm{km}$ crust directly beneath the valley, the differential isostatic correction between the center of the valley and the margins at Signal Mountain and Pilot Knob might be as much as $9 \mathrm{mgal}$. This would give rise to a thickness estimate closer to 12,000 feet than the 8000-foot average indicated in Figure 13 for a single density contrast. Thus, the discrepancy between computed and known minimum thickness might be at least partially explained in this way, although the assumptions are so extreme as to make a correction of as much as $9 \mathrm{mgal}$ highly unlikely. Therefore, even if local isostatic compensation is wholly or partially achieved, we believe that some density changes within and be- 


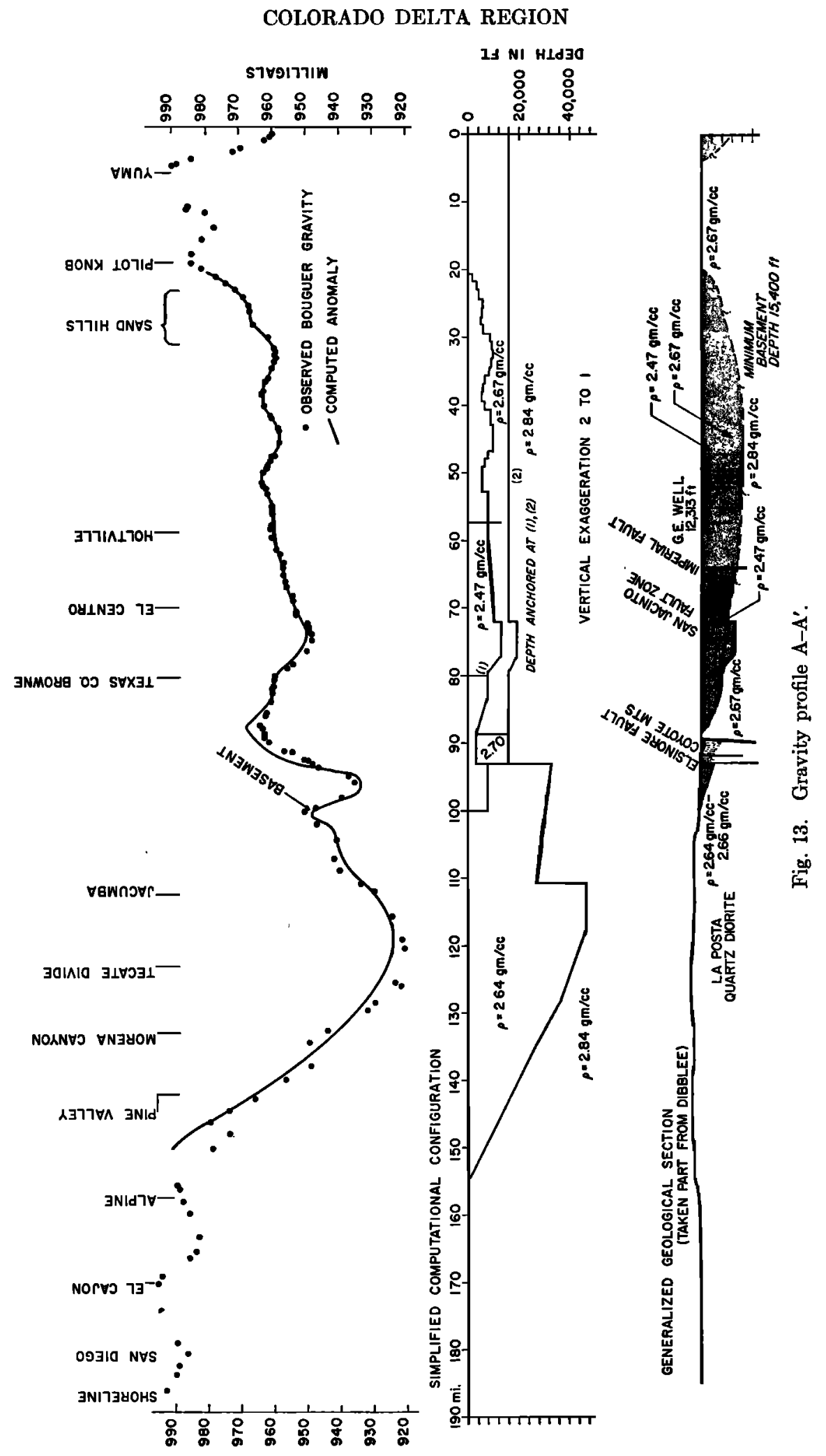


neath the sedimentary section are necessary to explain the observed gravity anomaly.

The effects of lateral density variations within the pre-Tertiary basement rocks are almost certainly superposed on this Bouguer anomaly field. Near Brawley, California, there are two fairly symmetrical gravity maxima (Fig. 5). Since the values at these maxima are only -10 to -15 mgal relative to bedrock areas in the Superstition Mountains and at Signal Mountain, it is again difficult to explain these anomalies by a thickening of the sediments alone. If we assume that the larger gravity maximum, east of Brawley, is caused only by gravity effect of a simple geometric form such as a sphere, we can estimate the depth to the center of the anomalous mass. From the width of this 8-mgal anomaly at half-amplitude the depth to the center of the anomalous mass is found to be 22,000 feet. Since seismic profile 3 on the east flank of this gravity maximum indicated a basement depth of 10,000 feet, we can conclude that density variations within the basement are contributing to the observed gravity in this region. This does not preclude relief on the basement floor contributing to these observed gravity maxima, but it is difficult to explain these anomalies solely on the basis of basement relief. In the absence of magnetic data which would yield information on variations within the basement rocks, a further analysis is not justified.

A zone of gravity gradient of about 4 to 5 $\mathrm{mgal} / \mathrm{mile}$ is present where the Superstition Hills fault and the Superstition Mountain fault appear to join to the northwest if one would visually extend their fault traces in this direction. The gravity gradient zone suggests the northwesterly convergence of these two faults. It is believed that these faults represent the southern continuation of the San Jacinto fault zone, which is probably 4 to 6 miles wide in this region. Several earthquake epicenters lend support to this statement.

West of El Centro is a large gravity minimum which can be interpreted as being caused by a thickening of the Cenozoic sediments in the Seeley basin (see gravity profile B-B'). The isogal contours defining this local minimum are bent or 'kinked' in the vicinity of $\mathrm{El}$ Centro along the projected strikes of the Superstition Hills fault and the Superstition Mountain fault. This distortion of the gravitational field indicates that these two faults continue at least as far south as Heber, California, and probably converge into one fault, as their projected strikes indicate.

On the northeast side of the Sierra de los Cucapas is a northwestward-trending zone characterized by a fairly steep gravity gradient which reflects the rapid rise of the basement towards the Cucapas. It is believed that this entire rapid rise of the basement is a reflection of the San Jacinto fault zone which, if projected from the northwest, would pass through the gravity gradient zone. However, it is not possible to identify individual fault breaks within the fault zone in this region.

Near Yuma, Arizona, there are two very pronounced gravity maxima. The gravity maximum west of Yuma corresponds to the basement outcrop of Pilot Knob. In the gravity maximum south of Yuma the Bouguer anomaly is equal to the maximum value for the delta region. This anomaly is a reflection of a very shallow basement south of Yuma. Early in 1920, a hole was drilled 5 miles south of Yuma, and granite was encountered at 730 feet [Butler and Allen, 1921]. Pilot Knob and this shallow basement near Yuma define the eastern limit of the Gulf of California structural trough in this region.

\section{Gravity Profiles}

The gravity profiles were analyzed by means of the computational techniques of Talwani, Worzel, and Landisman [1959] and Bott [1960]. Since the gravity profiles discussed here are either east-west or are tied to basement 'anchor points at both ends of the profile, no removal of a regional field is necessary.

Profile $A-A^{\prime}$ (Fig. 13). The observed Bouguer anomalies are shown for a 190-mile section along U. S. Highway 80 from Yuma, Arizona, to San Diego, California. The anomaly is about -20 mgal in the Yuma area, and it drops off to an average value of $-40 \mathrm{mgal}$ on the valley floor.

The dominant feature of the gravity profile is the sharp negative anomaly associated with the Peninsular Ranges. Between Pine Valley and the Jacumba area the Bouguer anomaly steeply drops off to a value of about $-80 \mathrm{mgal}$. The observed gravity gradient to this minimum is about 2 to $3 \mathrm{mgal} / \mathrm{mile}$ along U. S. Highway 80 . 
Let us first assume that this negative anomaly was caused by local crustal thickening under the Peninsular Ranges. Assuming a crust-mantle density contrast of $-0.45 \mathrm{~g} / \mathrm{cm}^{3}$, a 'step' in the $\mathrm{M}$ discontinuity from 35 to $45 \mathrm{~km}$ would only produce a maximum gravity gradient of about $1.5 \mathrm{mgal} / \mathrm{mile}$. Therefore, reasonable crustal thickening alone cannot account for the sharp negative anomaly. Furthermore, additional data [Press, 1956; Shor and Raitt, 1958] indicate that a normal continental crustal thickness is present under the Peninsular Ranges. Between Pine Valley and the gravity minimum at Tecate Divide, a distance of 23 miles $(37 \mathrm{~km})$, the Bouguer gravity changes by about $58 \mathrm{mgal}$. Using the relation $Z<\pi^{-1} X_{\mathrm{max}} \log \left(4 k \rho X_{\mathrm{max}}\right\}$ $\left.g_{\max }\right\}$ derived by Bullard and Cooper (1948) we can arrive at a limit to the depth that can be assumed for the material which produces the gravity anomaly. Assuming that the anomaly is caused by a density contrast in the range of -0.1 to $-0.25 \mathrm{~g} / \mathrm{cm}^{\mathrm{s}}$, a maximum depth between 6 and $17 \mathrm{~km}$ is indicated for the mass: which produces the gravity anomaly.

The association of negative anomalies with intrusive masses of silicic rock has been commonly observed [Bott, 1953; Oldham, 1958; Woollard, Ostenso, Thiel, and Bonini, 1960] and this explanation of the gravity minimum must be considered.

The batholith of southern California, made up of many separate plutons, occupies the core of the Peninsular Ranges. An examination of the areal geologic map along U. S. Highway 80 [Gastil and Bushee, 1961] shows that this gravity minimum coincides with one pluton-the La Posta quartz diorite pluton. Bulk dry densities of rock samples collected from the $\mathrm{La}$ Posta pluton from seven different localities ranged from 2.64 to $2.66 \mathrm{~g} / \mathrm{cm}^{2}$. Various tonalite and gabbro bodies are found in contact with the La Posta pluton. Samples of the tonalites collected from four different localities ranged in density from 2.70 to $2.82 \mathrm{~g} / \mathrm{cm}^{3}$. No density samples were collected from the gabbros, but 2.90 to $3.00 \mathrm{~g} / \mathrm{cm}^{\mathrm{s}}$ is a reasonable density range to assume.

Even though extensive sampling was not done

${ }^{3} X_{\max }$ is distance in kilometers between maximum and minimum value of $g, \rho$ is density in $\mathrm{g} /$ $\mathrm{cm}^{8}, k$ is the gravitational constant, $g$ is the anomaly in gals, $Z$ is the depth in kilometers. in this region, it is significant that samples from the La Posta pluton were less dense than samples from any of the surrounding plutons, and this fact suggests that the negative anomaly is a result of the density contrast between the La Posta pluton and the surrounding rocks.

In Figure 13 we have computed a two-dimensional anomaly, based on the simplified configuration shown, which is in agreement with the observed Bouguer gravity. The gravity anomaly is anchored to the Texas Company's Browne well, which gives the depth to basement on the west side of the Imperial Valley. A mean sediment-basement density contrast of $-0.20 \mathrm{~g} / \mathrm{cm}^{3}$, compatible with density samples from the Browne well, was chosen for the computations. A density of $2.64 \mathrm{~g} / \mathrm{cm}^{2}$, which represents a minimum value of density measured for samples of the La Posta pluton, was selected to explain the mass deficiency under the Peninsular Ranges. We have also projected into our gravity profile the Grupe-Engebretson well, which bottomed at 12,300 feet in sediments, and seismic profiles 5 and 6 , which indicated a minimum basement depth of 15,400 feet.

As was pointed out earlier, the Bouguer gravity difference between bordering bedrock areas and the central part of the Imperial Valley is not large enough to explain the thickness of sediments indicated by the refraction measurements. It is readily seen that carrying the 2.47- to 2.67$\mathrm{g} / \mathrm{cm}^{\mathrm{s}}$ interface, which represents basement at the Browne well, eastward into the center of the valley gives a depth that does not agree with the Grupe-Engebretson well, nor with the minimum seismic depth to basement. Therefore, in this region we have anchored our anomaly curve to a depth of 15,400 feet, selecting $2.84 \mathrm{~g} / \mathrm{cm}^{\text {a }}$ as the basement density compatible with the 18,$180-\mathrm{ft} / \mathrm{sec}(6-\mathrm{km} / \mathrm{sec})$ to $20,000-\mathrm{ft} / \mathrm{sec}(6.6-\mathrm{km} /$ sec) basement velocities measured by the refraction measurements.

A completely erroneous picture would be obtained if a single-layer sediment-basement density contrast were assumed. The 2.47- to 2.67$\mathrm{g} / \mathrm{cm}^{2}$ interface shown is meaningless for defining relief on the basement in the central part of the valley. Furthermore, since our assumptions are oversimplified, the variations in the shape of this interface are not real. The model shown is only a first-order approximation to the very complex density distribution in the earth's upper 
crust. Because of uncertainties in the inferred size of the mass anomaly in the Peninsular Ranges, horizontal and lateral density variations within the sedimentary section, and density variations within the basement rocks, a more detailed analysis is not justified at this time.

Profile $B-B^{\prime}$ (Fig. 14). This gravity profile is anchored to the Texas Company's Browne well, which bottomed in 'granite' at 7806 feet. Between basement outcrops at nearby Signal Mountain and this well, the total gravity relief is about 19 to $20 \mathrm{mgal}$, and so an appropriate mean density contrast of $-0.20 \mathrm{~g} / \mathrm{cm}^{\mathrm{s}}$, in agreement with density samples from the Browne well, was selected between the Cenozoic sediments and the pre-Tertiary basement in this region. We can also approximate a gradual in- crease of density with depth by computing the gravity anomaly for a two-layer sediment problem. Also shown in Figure 14 is a two-layer density model, compatible with density measurements in the Browne well, which also gives a very good fit to the observed data. The indicated depth for the Seeley basin is 12,900 feet for the one-layer problem and 11,800 feet for the two-layer problem. This gravity profile crosses roughly at right angles to the projected strike of the San Jacinto fault zone from the northwest. A small step in the observed gravity is present across the apparent continuation of the San Jacinto fault zone. It is significant that a vertical displacement of about 1870 feet was necessary in both models to match the observed anomaly in this region. If basement density in-

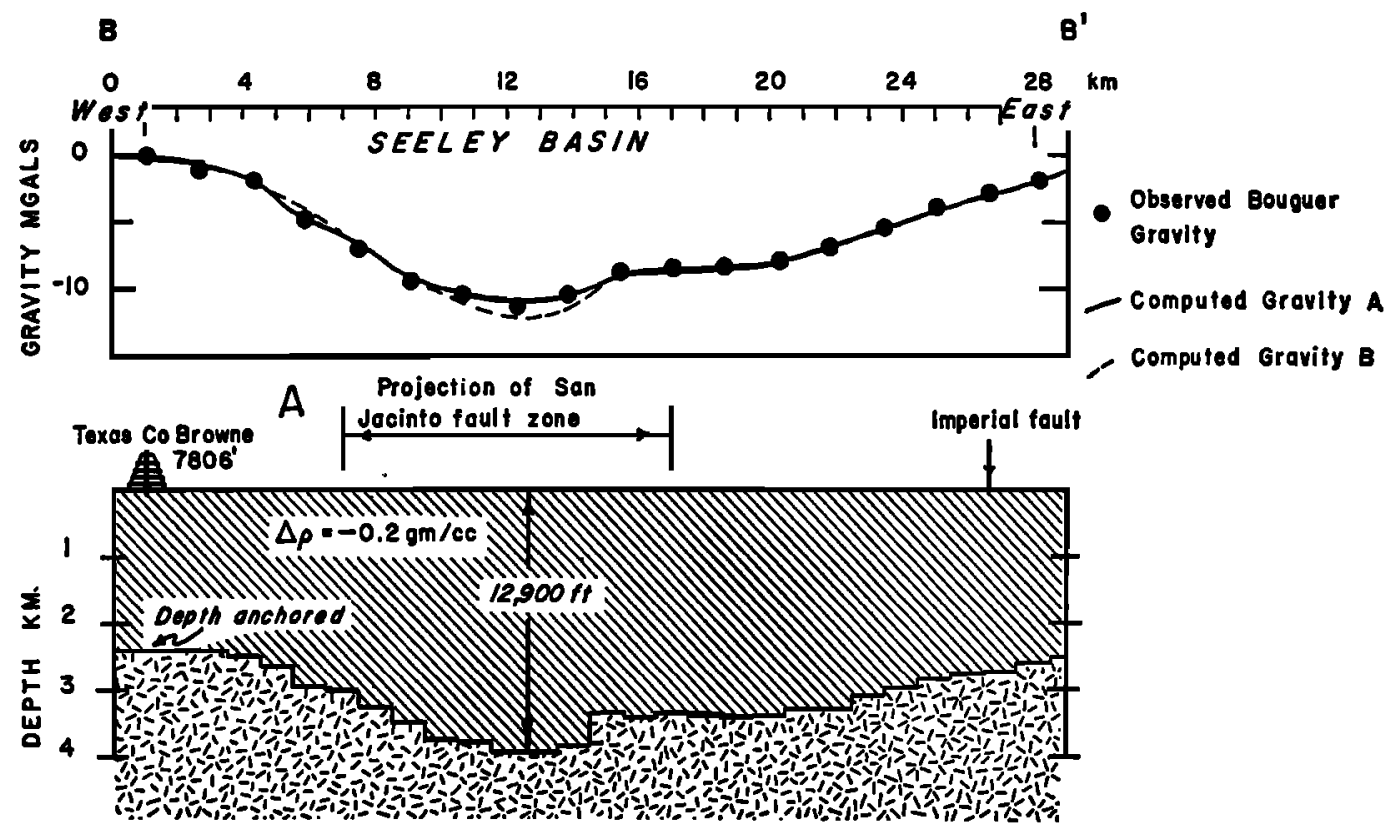

B

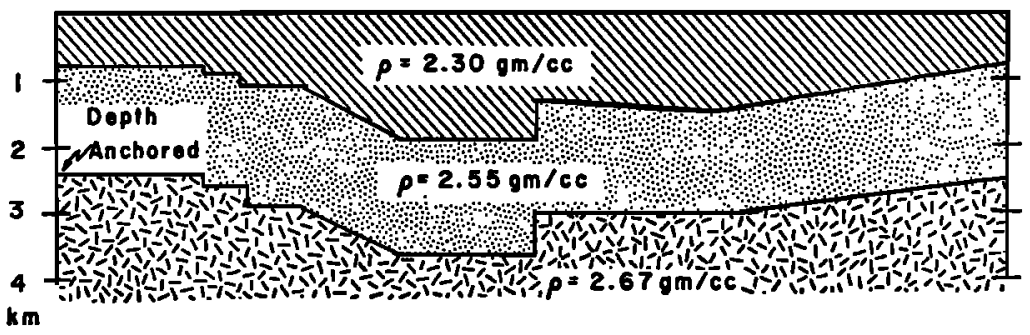

Fig. 14. Gravity profile B-B'. 
creases eastward across this fault zone, a greater vertical displacement is probably necessary. In view of profile $A-A^{\prime}$, which suggests density variations within the basement, the indicated basement depth shown in Figure 14, east of the San Jacinto fault zone, may be incorrect.

Profile $C-C^{\prime}$ (Fig. 15). This east-west gravity profile is tied at the west end to basement at the Sierra de los Cucapas. A significant gravity gradient of about $4 \mathrm{mgal} / \mathrm{mile}$ is visible crossing the projected trace of the San Jacinto fault zone. Also shown in Figure 15 in the delta region is the approximate location of a Recent fault break which is visible in aerial photographs taken in 1935 as a fault scarp in the alluvium. Under the assumed density contrast of -0.27 $\mathrm{g} / \mathrm{cm}^{\mathrm{a}}$, a vertical displacement of about 6700 feet is indicated crossing the fault zone.

Profile $D-D^{\prime}$ (Fig. 16). This north-south gravity profile crosses the south end of Laguna Salada and is tied to basement outerops of the Sierra Mayor and the Sierra Pinta. Striking evidence is shown on this gravity profile that Laguna Salada is a graben or down-dropped fault block between the Sierra Mayor and the Sierra Pinta. Under the assigned density contrast of $-0.27 \mathrm{~g} / \mathrm{cm}^{3}$ the indicated vertical displacement on the bounding faults is about 15,000 feet.

Profile $E-E^{\prime}$ (Fig. 17). It has been speculated that a major fault, trending from northwest to southeast, is present beneath the Sand Hills and that it represents either the direct continua- tion of the Mission Creek-Banning fault (San Andreas) from the north or is offiset en échelon from this fault. An examination of the gravity map of this region shows that the total gravity relief across the Sand Hills is not large. The gravity relief across the Sand Hills along the Brawley-Glamis road is about 6 to $7 \mathrm{mgal}$, between seismic profiles 1 and 2 it is about 6 mgal, and along U. S. Highway 80 about $8 \mathrm{mgal}$. This fact suggests that, if a major fault is present in this region, at least no major vertical displace'ment is evident. North of the present area of investigation the gravity gradient crossing the Mission Creek-Banning fault is about $8 \mathrm{mgal} /$ mile (Shawn Biehler, personal communication).

Figure 17 shows the gravity observed at halfmile intervals across the Sand Hills along the Brawley-Glamis road between the Coachella Canal and Glamis. Seismic profiles 1 and 2 were shot on opposite sides of the Sand Hills, about 8 miles southeast of this gravity profile. Since gravity data were not obtained directly across the Sand Hills between these seismic profiles, a compromise was effected by 'projecting' the measured basement depths onto the profile along the Brawley-Glamis road. Since the seismic profiles indicated essentially no dip on the basement, projecting these depths northward probably introduces no gross error in the depth to the basement. Seismic profile 1, on the east side of the Sand Hills, indicated a depth to basement of about 2200 feet. One may argue that perhaps this seismic profile did not truly indicate base-
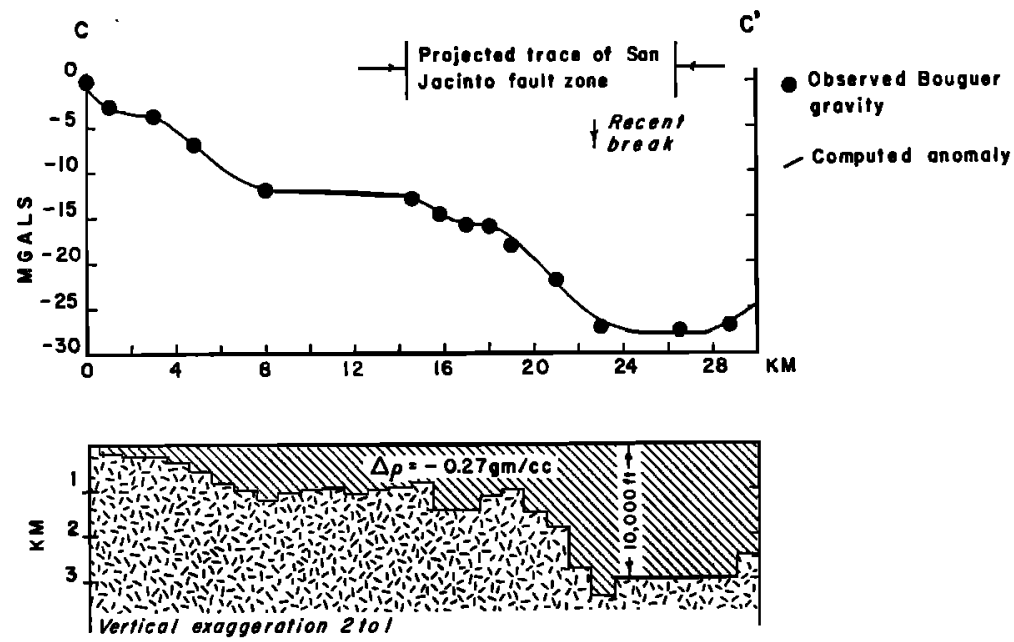

Fig. 15. Gravity profile $\mathrm{C}-\mathrm{C}^{\prime}$. 


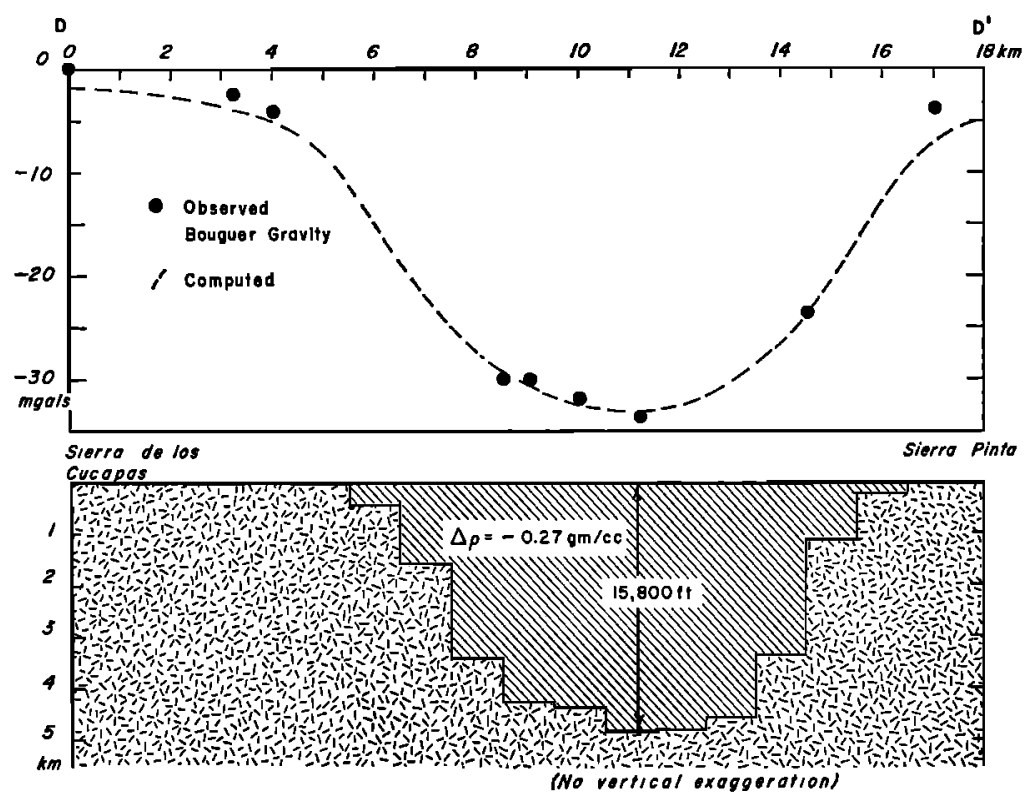

Fig. 16. Gravity profile D-D'.

ment velocity but a high-velocity volcanic layer; consequently, the computed basement depth is too shallow. However, the Ajax Oil Company's Phyllis well was drilled about 8 miles northwest of Glamis on the east flank of the Sand Hills, reaching basement at a depth of 2804 feet. We believe, therefore, that the seismic depth measurement is correct.

In the two-dimensional configuration shown in Figure 17, we have fixed the basement depth at 2200 feet on the east side of the Sand Hills and at 9372 feet on the west side, as measured by seismic profile 2 . A first attempt was made to explain the observed anomaly by using a sediment-basement density contrast only. With the basement configuration shown and with the basement depth fixed at both ends of the profile, a gravity anomaly was computed for a sediment-basement contrast of $-0.10 \mathrm{~g} / \mathrm{cm}^{3}$. It is readily seen that a basement configuration could presumably be computed, using a contrast of about $-0.10 \mathrm{~g} / \mathrm{cm}^{8}$, that would give the observed Bouguer anomaly. However, in view of the density measurements made on the Tertiary sediments we consider such a low contrast to be unreasonable.

Let us now assume that a strike-slip fault was present under the Sand Hills which brought into contact basement rocks of different densities.
The solid curve in Figure 17 shows the computed anomaly for a sediment density of 2.37 $\mathrm{g} / \mathrm{cm}^{3}$ and basement densities of 2.74 and 2.63 $\mathrm{g} / \mathrm{cm}^{2}$ in fault contact. The density variation in the basement was assumed to extend about 33,000 feet beneath the surface. Since the computations were made using density contrasts, the assigned densities are only relative, and no attempt should be made to assign specific rock types to these densities. However, a density contrast of $0.11 \mathrm{~g} / \mathrm{cm}^{3}$ within the basement is not geologically unreasonable, since granites $(\rho=$ 2.62 to $2.65 \mathrm{~g} / \mathrm{cm}^{3}$ ) against granodiorites ( $\rho=$ 2.68 to $2.74 \mathrm{~g} / \mathrm{cm}^{9}$ ) could produce this contrast.

As can be seen in Figure 17, the solid curve gives an excellent fit to the observed anomaly. The gravity interpretation in terms of these mass anomalies is certainly not unique. For example, the depth to which the density variation in the basement extends can only be assumed, and presumably other sediment and basement density configurations could be used. Furthermore, the deviation of some of the observed values from the computed smooth curve strongly suggests that density variations, probably associated with faulting, exist within the Tertiary section across the Sand Hills. In any event, it seems clear that we must accept some sort of density variation across the Sand Hills or ac- 

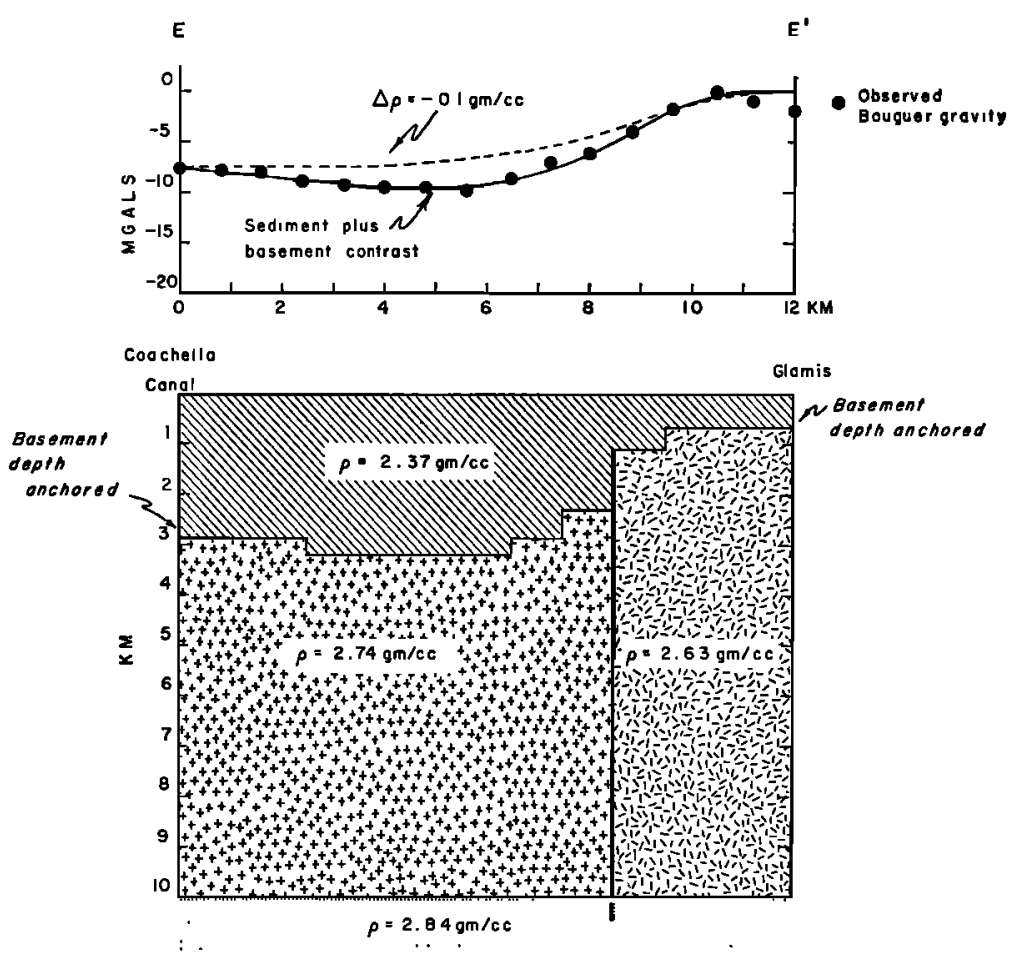

Fig. 17. Gravity profile E-E'

cept an abnormally low sediment-basement density contrast. For this reason we believe that a fault is present beneath the Sand Hills, but because of the inherent ambiguities in a gravity interpretation we cannot precisely locate it.

The extreme linearity of the southwestern edge of the Sand Hills has led many investigators to propose faulting in this region. However, if our interpretation is valid, the main fault break is much nearer to the northeastern edge of the Sand Hills than to the southwestern edge. A fault in the northeastern part of the Sand Hills is even less likely to be a direct prolongation of the Mission Creek-Banning fault than a fault on the southwest edge of the dunes would be.

\section{Conclusions}

The over-all trend of the isogal contours is northwesterly, in agreement with the major tectonic grain of the Gulf of California structural province. This is additional evidence that the Colorado delta region is indeed a part of the Gulf province.

In the central part of the Imperial Valley, gravity data alone are not too useful for de- termining sedimentary thicknesses. The gravity field is complicated by vertical and lateral density variations within the Tertiary section and by lateral density variations within the preTertiary basement. It is possible that isostatic compensation of the low-density sediments has masked the gravitational effect of the sediments themselves.

Continuity of specific major faults in the delta region is difficult to establish by gravity methods alone because of the lack of indicated vertical throw on the faults. Even where well exposed to the northwest, the San Jacinto and Elsinore faults consist of wide zones of branching and interlacing breaks, so that the question is more one of continuity of fault zones than of continuity of individual single breaks through the delta region. Nevertheless, continuity of the Elsinore fault to the Laguna Salada fault can be established because of the steep gravity gradient zone which can be traced along the west side of the Cucapas to the Elsinore fault to the north.

The Superstition Mountains were elevated along the faults of the San Jacinto zone. The 
Superstition Mountain fault and the Superstition Hills fault can be traced at least as far south as Heber, California, using the gravity data. For 50 miles southeast from Cerro Prieto, a major throughgoing fault, believed to belong to the San Jacinto zone, is visible on aerial photographs of the delta region as a fault scarp in the alluvium. Both northwest and southeast of Cerro Prieto a zone of steep gravity gradient is present along the projected strike of the San Jacinto zone from the north, although it is not possible to define specific breaks within this zone. Even though continuity of the San Jacinto fault zone through the delta region cannot be firmly established in some areas with gravity data alone, it seems fairly certain that continuity of this fault zone can be established by the additional data provided by seismicity.

No conclusive evidence is presented for establishing the continuity of the Mission CreekBanning fault southward into the present area of investigation. If our interpretation is valid, a fault is present beneath the Sand Hills, although our limited data indicate that the fault is closer to the east edge of the dunes than to the linear west edge of the dunes. It is difficult to extend the Mission Creek-Banning fault to the eastern part of the Sand Hills unless the fault plane curves to the east.

About 8 miles north of Plaster City, opposite Carrizo Creek, the seismic data indicate a basement depth of about 2700 feet. The basement probably deepens slightly toward the raised Superstition Mountain fault block and then deepens rapidly eastward from this range. Eight miles east of the Superstition Mountains, seismic data indicate basement depths of at least 11,400 feet. The basement deepens locally to about 12,000 feet in the Seeley area, west of EI Centro, and then is prominently exposed southward at Signal Mountain. Southwest of Signal Mountain is Laguna Salada, a graben that is lowered relative to the Cucapas and the Sierra Juárez. Gravity data suggest a depth of about 19,000 feet to the basement floor in Laguna Salada.

Northeast of Holtville, California, along the east margin of the cultivated region, the depth to basement is about 10,000 feet. The depth to the bedrock floor probably averages 9000 to 10 ,000 feet eastward to the Coachella Canal. Crossing the Sand Hills, the basement shallows rapidly to a depth of 2200 feet along the OgilbyGlamis road and is then exposed eastward at the Cargo Muchacho and the Chocolate Mountains.

Twelve miles east of Calexico, along the international border, the depth to basement is at least 15,400 feet. Thus, it can be stated that the relief between the crest of the Peninsular Ranges to the west and the subsurface bedrock floor approaches 20,000 feet in the central part of the delta region.

West of the Superstition Mountains and east of the Sand Hills, on the margins of the delta region, a layer with a velocity range of 6940 to $6970 \mathrm{ft} / \mathrm{sec}$ directly overlies the pre-Tertiary basement. The absence of sedimentary velocities greater than this 6940 - to $6970-\mathrm{ft} / \mathrm{sec}$ range probably indicates that a substantial portion of the Tertiary section, present elsewhere in the basin, is absent in these marginal areas. For the profiles shot in the central part of the delta region, several consistent velocity zones in the range 5650 to $15,500 \mathrm{ft} / \mathrm{sec}$ were present overlying the pre-Tertiary basement. Basement velocities ranged from 18,180 to $20,000 \mathrm{ft} / \mathrm{sec}$.

Seismic refraction data indicate a depth of about 21,000 feet to basement near the head of the Gulf of California, opposite San Felipe (George Shor, personal communication). Our seismic results reveal basement depths ranging from 10,000 to 15,000 feet in the Imperial Valley region of the Colorado delta, the greatest depths being indicated near the international boundary. It would thus be natural to assume that the gulf structural trough, in general, deepens to the south toward the head of the Gulf of California. However, the gravity data do suggest that basement shallowing occurs between the international border and head of the gulf.

Arknowledgments. Standard Oil Company of California released some gravity data for the Imperial Valley and provided a grant-in-aid for the seismic field work. Grateful acknowledgment is made to the Instituto de Geofísica of the Universidad Nacional de México for their collaboration in obtaining gravity measurements in Mexiro and to Ing. Julio Monges C., who participated in the field observations. The Texas Company released information on their Grupe-Engebretson well. Special thanks are due Dr. Charles Helsley for his support and advice throughout this investigation. Drs. J. Healy and R. Phinney and Messrs. D. Harkrider and S. Alexander assisted in the field work. Mr. Shawn Biehler provided most of the 
gravity stations in the Niland-Calipatria area. Additional financial support was provided by the American Petroleum Institute. The final stage of this research was provided for by the National Science Foundation grant G-19778. Drs. Robert P. Meyer and Manik Talwani made valuable criticisms during the preparation of the paper.

\section{REFERENCES}

Allen, C. R., San Andreas fault zone in San Gorgonio Pass, southern California, Bull. Geol. Soc. $A m ., 68,315-350,1957$.

Allen, C. R., L. T. Silver, and Francis Stehli, Agua Blanca fault-a major transverse structure of northern Baja California, Mexico, Bull. Geol. Soc. Am., 71, 457-482, 1960.

Beal, C. H., Reconnaissance of the geology and oil possibilities of Baja California, Mexico, Geol. Soc. Am. Mem. 31.1948.

Bott, M. H. P., Negative gravity anomalies over acid intrusions and their relation to the structure of the earth's crust, Geol. Mag., 90, 257267, 1953.

Bott, M. H. P., The use of rapid digital computing methods for direct gravity interpretation of sedimentary basins, Geophys. J., S, 63-67, 1960.

Bullard, E. C., and R. I. B. Cooper, The determination of the masses necessary to produce a given gravitational field, Proc. Roy. Soc., London, A, 194, 332-347, 1948.

Butler, G. M., and M. A. Allen, Petroleum, Univ. Ariz. Bull. 116, 1-45, 1921.

Dibblee, T. W., Jr., Geology of the Imperial Valley region, California, Calif. Div. Mines Bull. 170, 21-28 (chapter 2), 1954.

Dix, C. H., Seismic Prospecting for Oil, Harper and Brothers, New York, 1952.

Downs, T., and G. Woodard, Middle Pleistocene extension of the Gulf of California into the Imperial Valley, paper presented orally at annual meeting Cordilleran Section, Geological Society of America, San Diego, 1961.

Duerksen, J. A., Pendulum gravity data in the United States, U. S. Coast and Geod. Survey Spec. Publ. 244, 1949.

Gastil, Gordon, and J. Bushee, Geology and geomorphology of eastern San Diego County, in Guidebook for Field Trips, 57th annual meeting, San Diego, Cordilleran-Section, Geological Society of America, 8-22, 1961.

Gutenberg, B., and C. F. Richter, Seismicity of the Earth, Princeton University Press, Princeton, N. J., 273 pp., 1949.

Hamilton, Warren, Origin of the Gulf of California, Bull. Geol. Soc. Am., YR, 1307-1318, 1961.

Hammer, Sigmund, Terrain corrections for gravimeter stations, Geophysics, 4, 184-194, 1939.

Kniffen, F. B., Lower California studies, 4, The natural landscape of the Colorado delta, Univ. Calif. Publ. in Geography, 5, 149-244, 1932.

Larsen, E. S., Jr., Batholith and associated rocks of Corona, Elsinore, and San Luis Rey quadrangles, southern California, Geol. Soc. Am. Mem. 29, 1-182, 1948.

Lindgren, W., Notes on the geology of Baja California, Mexico, Proc. Calif. Acad. Sci., 1, 173$196,1888$.

Nettleton, L. L., Geophysical Prospecting for Oil, McGraw-Hill Book Co., New York, 444 pp., 1940.

Oldham, C. H. G., Gravity and magnetic investigations along the Alaska Highway, Publs. Dominion Obs. Ottawa, 21, 1-22, 1958.

Press, F., Determination of crustal structure from phase velocity of Rayleigh waves, 1, Southern California, Bull. Geol. Soc. Am., 67, 1647-1658, 1956.

Richter, C. F., Elementary Seismology, W. H. Freeman and Co., San Francisco, 768 pp., 1958.

Shor, G. G., Jr., Preliminary report on seismic refraction survey, Gulf of California, Am. Petrol. Inst. Research Proj. 61, Quart. Rept. 1, 1-12, 1959.

Shor, G. G., Jr., Crustal structure in the San Diego, California, area (Abstract), Geol. Soc. Am. Spec. Paper 68, 55, 1962.

Shor, G. G., Jr., and R. W. Raitt, Seismic studies in the southern California continental borderland, Geol. Intern. Congr., Seccion 9, 20th Congr., Mexico, D. F., 253-259, 1958.

Talwani, M., J. Worzel, and M. Landisman, Rapid gravity computations for two-dimensional bodies with application to the Mendocino submarine fracture zone, J. Geophys. Research, 64, 49-59, 1959.

Tsuboi, Chuji, Crustal structure in northern and middle California from gravity-pendulum data, Bull. Geol. Soc. Am., 67, 1641-1646, 1956.

Ulrich, F. P., The Imperial Valley earthquakes of 1940, Bull. Seism. Soc. Am., 31, 13-31, 1941.

Vyskočil, Vincenc, The determination of the shape of a boundary between two media from gravitational data for varying density with depth, Geofys. Sbornik (Publ. of the Geophys. Inst. of the Czechoslovak Academy of Sciences, Prague), 4, 1-21, 1956.

Woollard, G. P., Transcontinental gravitational and magnetic profile of North America and its relation to geological structure, Bull. Geol. Soc. Am., 54, 747-789, 1953.

Woollard, G. P., N. A. Ostenso, E. Thiel, and W. E. Bonini, Gravity anomalies, crustal structure, and geologv in Alaska, J. Geophys. Research, 65, 1021-1037, 1960.

(Manuscript received February 12, 1962; revised May 2, 1962.) 